\title{
HEINONLINE
}

Citation: 31 Law \& Soc. Inquiry 1092006

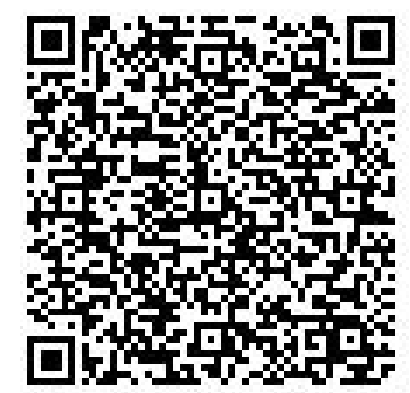

Content downloaded/printed from

HeinOnline (http://heinonline.org)

Fri Oct 16 16:17:11 2015

-- Your use of this HeinOnline PDF indicates your acceptance of HeinOnline's Terms and Conditions of the license agreement available at http://heinonline.org/HOL/License

-- The search text of this PDF is generated from uncorrected OCR text.

-- To obtain permission to use this article beyond the scope of your HeinOnline license, please use:

https://www.copyright.com/ccc/basicSearch.do?

\&operation $=$ go\&search $T y p e=0$

\&lastSearch $=$ simple\&all=on\&titleOrStdNo=0897-6546 


\section{Through the Back Door: Applying Theories of Legal Compliance to Illegal Immigration During the Chinese Exclusion Era}

This article applies theories of legal compliance to analyze the making of this country's first "illegal immigrants"-Chinese laborers who crossed the U.S.-Canadian and U.S.-Mexican borders in defiance of the Chinese exclusion laws (1882-1943). Drawing upon a variety of sources, including unpublished government records, I explore the ways in which Chinese laborers gained surreptitious entry into the United States during this period and ask, what explains their mass noncompliance? I suggest that while an instrumental perspective is useful for understanding these border crossings, it overlooks other important determinants of noncompliance: normative values and opportunity structures. Specifically, the exclusion laws were widely perceived by the Chinese as lacking social and moral legitimacy, and thus not worthy of obedience. In addition, the existence of smuggling networks and liberal immigration policies in Canada and Mexico played a critical role in facilitating noncompliance. The article concludes with a discussion about the benefits and challenges of using this theoretical framework to analyze noncompliance in immigration law.

Emily Ryo is a Ph.D. candidate in Sociology at Stanford University. This research is based upon work supported by the National Science Foundation Graduate Research Fellowship. She is deeply grateful to Michele Landis Dauber for her support and guidance. She also offers special thanks to Lawrence Friedman, Andrew Kim, Jason Odeshoo, Lucy Salyer, Rebecca Sandefur, and Carolyn Wong. Scott Forsythe and William Greene at the National Archives provided invaluable assistance. Direct all correspondence to eryo@stanford.edu. 
We cannot have too much immigration of the right kind, and we should have none at all of the wrong kind. The need is to devise some system by which undesirable immigrants shall be kept out entirely, while desirable immigrants are properly distributed throughout the country.

-President Theodore Roosevelt, December 7, 1903

\section{INTRODUCTION}

In 1882, Congress passed a law to stop the immigration of what it considered, at the time, one of the most "undesirable" group of aliens: Chinese laborers. Enacted during a period of virulent racism and xenophobia, the 1882 Chinese Exclusion Act and subsequent related laws (together, "Chinese exclusion laws") prohibited the immigration of Chinese laborers for over six decades (see, e.g., Gyory 1998; Lee 2003; Salyer 1995; Tsai 1986). The Chinese, however, did not silently submit to these laws; instead they challenged and circumvented them with indefatigable tenacity throughout the late nineteenth and the early twentieth centuries. ${ }^{1}$ One common method of evasion was surreptitious entry through the "backdoor" of Canada or Mexico, which helped to make Chinese immigrants this country's first "illegal immigrants" (Lee 2003, 13), long before Mexican immigrants came to fill this role in contemporary American discourse.

Because of the clandestine nature of their entry, it is difficult, if not impossible, to estimate the number of Chinese immigrants who crossed the border illegally during the exclusionary period. Existing estimates are few in number and speculative in nature. Lee $(2003,151)$ speculates that at least 17,300 Chinese immigrants entered the United States by illegally crossing the border between 1882 and 1920. Fry (1928), on the other hand, estimates that between 7,000 and 21,000 Chinese were smuggled into the United States between 1910 and 1920 alone. Lau $(2000,91)$, in contrast, points out that according to a 1901 report from the House Committee on Immigration, approximately 20,000 Chinese were smuggled into the United States each year. It is possible, then, that surreptitious entry may have been an even more popular method of illegal immigration than posing as "paper sons"3another common method of evasion used by the Chinese to enter the United States during the exclusion era. Under this latter method, a Chinese would

1. For analyses of legal challenges brought by Chinese immigrants during the exclusion era, see Fritz 1988; McClain 1994; Salyer 1995.

2. "Illegal" may be a politically and emotionally charged label that raises a number of thorny issues when discussing immigrants or immigration (see Lee 2003, 149-150; Ngai 2004, $x i x-x x)$. Despite my reservations, I use the term throughout this article because it remains the most conventional and widely understood term that refers to the state of being in violation of a country's established immigration law.

3. Although there were also some "paper daughters," the vast majority of Chinese who entered using this method were male (Daniels 2004, 24). For paper daughters, see Yung 1995, 1998. 
pose as a son of a Chinese U.S. citizen or a minor son of a Chinese merchant, which made them eligible for entry under the exclusion laws. Over 11,000 Chinese immigrants reportedly admitted to entering the United States as paper sons under the 1957 law offering them immunity and legalization, and approximately another 19,000 were implicated by these confessions as holding false U.S. citizenship (see Chen 1980, 177; Ngai 1998, 22). ${ }^{4}$

While paper sons have been studied quite extensively (see, e.g., Fong 1999; Hsu 1997, 2000; Lai 2004; Lau 2000; Ngai 2004; Wong and Klein 1994), Chinese border crossers of the exclusion era have received relatively scant attention. ${ }^{5}$ One notable exception is Erika Lee's detailed and comprehensive study of Chinese immigration throughout the exclusionary period, which includes a rare historical sketch of Chinese exclusion along the U.S.-Canadian and U.S.-Mexican borders (2003, 151-87). In brief, Lee's book argues that the Chinese experience was a critical element in the racial formation of nineteenth- and early-twentieth-century America and the transformation of the country into a gate-keeping nation. While Lee's seminal work on Chinese border crossings during the exclusion era is uniquely rich and insightful in its historical narrative, there remains a wide array of theoretical and empirical issues that may be analyzed from a socio-legal perspective.

The relative dearth of scholarly research on this topic may be attributable to the difficulties inherent in obtaining data on a phenomenon that was by its very nature, clandestine and devoid of paper trails. In comparison, paper son schemes generated thousands of pages of transcripts of interviews between Chinese immigrants and U.S. officials, as well as other documents such as "coaching papers," which the paper sons used to educate themselves about their paper families. In addition, because illegal border crossers did not have the opportunity to later confess their unlawful mode of entry and to legalize their status-unlike paper sons - their stories never became part of the public consciousness to the same extent. It is also possible that compared to the stories of paper sons, which are often replete with images of tense confrontations between Chinese immigrants and U.S. officials, and of elaborate intrigues involving prefabricated family histories, accounts of surreptitious entries may appear relatively less romantic or dramatic to some observers. In this respect, the gap in research may also be due in part to a failure of scholarly imagination.

4. These figures are inconsistent with another source that places the number of confessions at 8,000 (Chinn, Lai, and Choy 1969, 28; see also Calavita 2000, 27; Salyer 1995, 44). Since Chinn et al. (1969) does not provide a source for its statement, I rely on the statistics provided by Chen (1980) and Ngai (1998), which are drawn from the published Annual Reports of the Immigration and Naturalization Service (INS). However, these numbers also should be considered with caution, as INS statistics often have been shown to be inaccurate and compromised by the agency's need to justify expanded budgets (Daniels 2004, 157).

5. For analyses of contemporary illegal Chinese immigration, see Chin 1999; Kwong 1997. 
Regardless of the reasons for the neglect, illegal Chinese border crossings during the exclusion era constitute a critical aspect of early American immigration history, and they present a unique opportunity to apply and extend existing theories of legal compliance. Though studies of legal noncompliance have a long tradition in law and society research, problems of noncompliance in immigration law have never been analyzed within this theoretical framework. This article represents the first attempt to undertake this task, using the case study of these early Chinese border crossers. Given the complexity of the phenomenon and the qualitative nature of the empirical data available, however, the aim of this article is not to present a rigorous scientific "test" of the theories, but rather, to delineate the contours of the problem using the approach developed within the legal compliance literature. In the process, I hope to open up further theoretical and empirical inquiries into the origins and causes of illegal immigration, a phenomenon that has become a policy concern of great significance in contemporary America.

Summarized briefly, the main insight that emerges from my analysis of illegal Chinese border crossings during the exclusion era is that noncompliance with immigration law is likely a function of not only instrumental reasons, but also normative values and opportunity structures. To be more specific, there is no denying that deteriorating political and economic conditions in China and the great demand for unskilled labor in the United States constituted strong "push" and "pull" factors, respectively, for illegal Chinese immigration during this period (Hsu 2000; Lai 2004; Lee 2003; Tsai 1986; Zo 1978). While this instrumental perspective is useful, however, it overlooks the importance of normative values and opportunity structures for evasion that existed to facilitate and sustain this practice for decades. In brief, from a normative perspective, the exclusion laws were widely perceived by the Chinese as lacking social and moral legitimacy, and thus not worthy of obedience. Some border crossers even protested their detention or deportation in U.S. courts when their attempts proved unsuccessful. With respect to opportunity structures, the development of smuggling networks and the existence of liberal immigration policies in Canada and Mexico proved to be crucial in enabling noncompliance with the Chinese exclusion laws.

This article is divided into four major parts. Part I outlines the theoretical framework used in this article, highlighting the relevant findings from past research that focuses on the question, why do people obey (or disobey) the law? Part II provides a historical overview of the Chinese exclusion laws and the phenomenon of illegal Chinese border crossings, with a special focus on the U.S.-Canadian and U.S.-Mexican borders. This part also discusses actions taken by the federal government to try to enforce the border. In Part III, I suggest that to understand these border crossings, we must look beyond purely economic or instrumental arguments and consider other important determinants of noncompliance: normative values and opportunity structures to engage in noncompliance. Part IV concludes with a discussion 
about the benefits and challenges of using this theoretical framework to analyze noncompliance in immigration law.

In undertaking these tasks, this article relies on a variety of sources, including unpublished government records, legislative materials, court cases, newspaper accounts, and scholarly analyses. The government records used in this article are drawn from the National Archive's Immigration and Naturalization Service (INS) Records, Record Group 85, held at the Pacific Region (San Bruno, California) and the Great Lakes Region (Chicago, Illinois). These records are composed of a rich and diverse, albeit little-used, body of correspondence, memoranda, notes, case files, and reports, and they provide unique and invaluable insights into the nature of interactions between American immigration officials and illegal Chinese border crossers. ${ }^{6}$

\section{THEORETICAL FRAMEWORK}

Why do people obey or disobey the law? Because of its far-reaching theoretical and policy implications, this question has generated a large body of research over the years by scholars interested in understanding the nature and determinants of legal compliance. Early research on compliance, particularly in the area of criminal law, was dominated by the instrumental or deterrence view of compliance, which was heavily influenced by the law and economics tradition (see, e.g., Becker 1968; Posner 1972; Stigler 1970; for a helpful review, see Nagin 1998). Under the instrumental view, the decision to obey the law is a product of an individual's cost-benefit analysis. Noncompliance is likely if the rational actor's estimate of the expected benefit of committing an illegal act outweighs the estimate of the expected cost, which is assumed to be a function of the perceived certainty of arrest and severity of punishment (see, e.g., Gibbs 1986; Grasmick and Bryjak 1980; Tittle 1969). This is a highly instrumental view of compliance with the law, since people are viewed as "shaping their behavior to respond to changes in the tangible, immediate incentives and penalties associated with following the law" (Tyler 1990, 3).

In research on illegal immigration, the instrumental view has been highly influential. In most studies, there is an implicit assumption that illegal

6. Citations to archival materials will appear in footnotes throughout the article. Materials used in this article that are held at the National Archives, Great Lakes Region, have the following citation: Correspondence of the Chinese Division, 1893-1924; Records of Immigration and Naturalization Service, Record Group 85; National Archives, Chicago, IL (NAC). Materials used in this article that are held at the National Archives, Pacific Region, have the following citation: Microfilm Edition of Subject Correspondence Files, Part 1: Asian American and Exclusion, 1906-1913 (Part 1) and Supplement to Part 1, 1898-1941 (Supplement); Records of Immigration and Naturalization Service, Record Group 85; National Archives, San Bruno, CA (NAS). Hereinafter these materials will be identified by their file or microfilm roll numbers, followed by their repository abbreviations shown above. 


\section{LAW \& SOCIAL INQUIRY}

immigrants are simple rational utility-maximizers who cross the border based on economic calculations about the costs and benefits of their law-breaking behavior. According to Barry Chiswick $(1988,12)$, for example, "Illegal aliens exist because the desires of some to be in the United States for employment or other purposes come into conflict with U.S. efforts to regulate who may enter and remain in this country ... [and] because of the imperfect enforcement of immigration law." Even among noneconomists, illegal immigration has been explained, largely if not solely, in economic terms. As described by Laurence Fuchs $(1990,248)$, for example, illegal immigration has always existed because "[t]he most fundamental law of economics [is] at work: supply and demand." This rationalist or instrumental view is problematic, however, because it ignores two other factors that have been shown to be important in understanding noncompliance with the law in more recent research: (1) normative values, and (2) opportunity structures for noncompliance.

The normative view of compliance, in contrast to the instrumental view, posits that compliance is largely determined by a person's perception of what is just, moral, and legitimate, rather than material self-interests or fear of sanctions. The best known and most authoritative study regarding the connection between normative values and compliance behavior is Tom Tyler's Why People Obey the Law (1990). In this study, Tyler interviewed over 1,500 people about their views on and interactions with the law in their everyday lives and found that people's beliefs in the morality of the law and the legitimacy of legal authorities played a major role in their decisions to obey the law (see also Tyler and Darley 2000; Tyler and Huo 2002; Tyler 2003). Importantly, Tyler's basic findings about the significance of normative values in law-related behavior have been supported by a large number of other studies in a variety of different research and legal settings (see, e.g., Bachman, Paternoster, and Ward 1992 (sexual assault); Paternoster et al. 1997 (domestic violence); Robinson and Darley 1997 (criminal law); Smith 1992 (tax compliance)).

Another important determinant of legal compliance, which has a long history in the criminology literature, is what I will refer to as the opportunity structure for noncompliance. In basic terms, the opportunity structure for noncompliance refers to the presence of environmental factors (both structural and situational) that facilitate or enable the commission of an illegal act. Underlying this concept is the important, albeit rather basic and natural, principle, that "No matter how strong they may be, intentions cannot result in actions unless the opportunity to realize them is available" (Smith and Kinsey 1987, 646-47; see also Coleman 1987, 424). For example, as Meier and Morgan

7. In delineating four types of constraints on human behavior, Lawrence Lessig (1998, $663)$ describes a similar concept using the term "architecture": "That I cannot lift large objects is a constraint on my ability to steal... That there is a highway or train tracks separating this neighborhood from that is a constraint on citizens to integrate. These features of the world--whether made or found-restrict and enable in a way that directs or affects hehavior." 
$(1982,260)$ point out, "persons living in small Midwestern towns may not have the opportunity to violate a pornography or prostitution law. A small businessman may never have the chance to fix prices. Opportunities for noncompliance .... are thus often a function of the environment, which may be thought to include the physical, economic, social, and political setting."

The focus on environmental factors as a determinant of social deviance originated with the Chicago School (also known as the Ecological School) of thought. According to Clifford Shaw and Henry McKay (1942), low economic status, ethnic heterogeneity, and residential mobility lead to social disorganization at the community level, which in turn produces ripe conditions for juvenile delinquency. Richard Cloward and Lloyd Ohlin (1960), in their seminal study of delinquent gangs, were more explicit in their use of the term opportunity structure. In what became known as the Differential Opportunity Theory, they argued that potential deviants needed not only internal motivations, but also an environment that was conducive to learning deviance, and once trained, an opportunity to engage in deviance. According to Cloward and Ohlin (1960), this illegitimate opportunity structure was not equally available to all, which explained why only certain groups were likely to engage in criminal activity. In the more recent literature, opportunity structure has been explicitly modeled in such areas of research as corporate illegality (McKendall and Wagner 1997), tax evasion (Smith and Kinsey 1987), speed law violation (Meier and Morgan 1982), and the smuggling of goods across borders (Paulus and Simpson 1981).

Together, what the research on legal compliance that I have reviewed thus far suggests is that the probability of noncompliance with immigration law is likely a function of instrumental reasons, normative values, and opportunity structures within which the migrant is embedded. That is, given strong economic incentives to cross the border, if the law prohibits a person from doing so legally, normative values and opportunity structures could play a critical role in facilitating that process illegally. The remainder of this article will explore empirical evidence that might support and elucidate this proposition using the case of illegal Chinese border crossers from the exclusion era. But first, in order to place that discussion in its proper historical context, I sketch a brief overview of the Chinese exclusion laws and the ways in which Chinese immigrants became illegal border crossers during the late nineteenth century and into the early decades of the twentieth century.

\section{HISTORICAL OVERVIEW AND BACKGROUND}

\section{A. Chinese Exclusion Laws}

The Chinese Exclusion Act of 1882 (Act of May 6, 1882, ch. 126, 22 Stat. 58) was the first American immigration law to exclude an entire group 
of immigrants based solely on race, nationality, and class. When Chinese laborers first entered the United States during the California Gold Rush of 1848 and the building of the Central Pacific Railroad (1863-1869), they were initially welcomed. Indeed, the 1868 Burlingame Treaty between the United States and China guaranteed Chinese immigrants all the "privileges, immunities, and exemptions ... there may be enjoyed by the citizens or subjects of the most favored nation" (July 28, 1868, 16 Stat. 739, T.S. No. 48). However, with the end of the Gold Rush and the completion of the transcontinental railroad, the demand for Chinese labor began to decline drastically. With the depression that lasted between 1873 and 1878, Chinese immigrants increasingly became targets of extreme social and legal discrimination, as well as violent racial attacks by white laborers (Salyer 1995, 9-10).

Fears of economic competition from Chinese laborers were amplified by the prevailing notion that the Chinese were racially inferior and inherently inassimilable. In the words of Senator Addison McClure, a fervent advocate of the Chinese exclusion laws, Chinese were "[a]lien in manners, servile in labor, pagan in religion," and thus "fundamentally un-American" (quoted in Gyory 1998, 5). ${ }^{8}$ In the popular media, Chinese immigrants were often depicted as wily and devious creatures, whose growing "monopoly" over certain businesses and willingness to work for low wages put white workers out of their jobs. In Figure 1, for example, the Chinese laborer is portrayed as a hideous octopus-like caricature, taking over a variety of businesses while leaving white laborers unemployed on the streets. The caption, "What Shall We Do with Our Boys?" and the image of a boy being dragged off towards prison in the distance underscore the mounting fear among whites that Chinese laborers threatened not only their jobs, but the very fabric of social order and morality in America.

In the face of mounting racist hysteria that the country would soon be overrun by the "loathsome ... revolting . . . monstrosity" of Chinese immigrants (quoted in Gyory 1998, 5), the federal government responded by seeking a renegotiation of the Burlingame Treaty with China in 1880 . This new treaty gave the United States authority to "regulate, limit, or suspend" immigration of Chinese laborers, but not to "absolutely prohibit" immigration (November 17, 1880, 22 Stat. 826, T.S. No. 49). The 1880 Treaty also preserved the most-favored-nation-status clause and assured that the rights of Chinese in the United States would be protected, including the right of Chinese laborers already present in the United States to "go and come of their own free will and accord."

8. See also Chinese Exclusion Case $(1889,595)$, in which Justice Field declared, "The differences of race added greatly to the difficulties of the situation. . . . they remained strangers in the land, residing apart by themselves, and adhering to the customs and usages of their own country. It seemed impossible for them to assimilate with our people or make any changes in their habits or modes of living." 

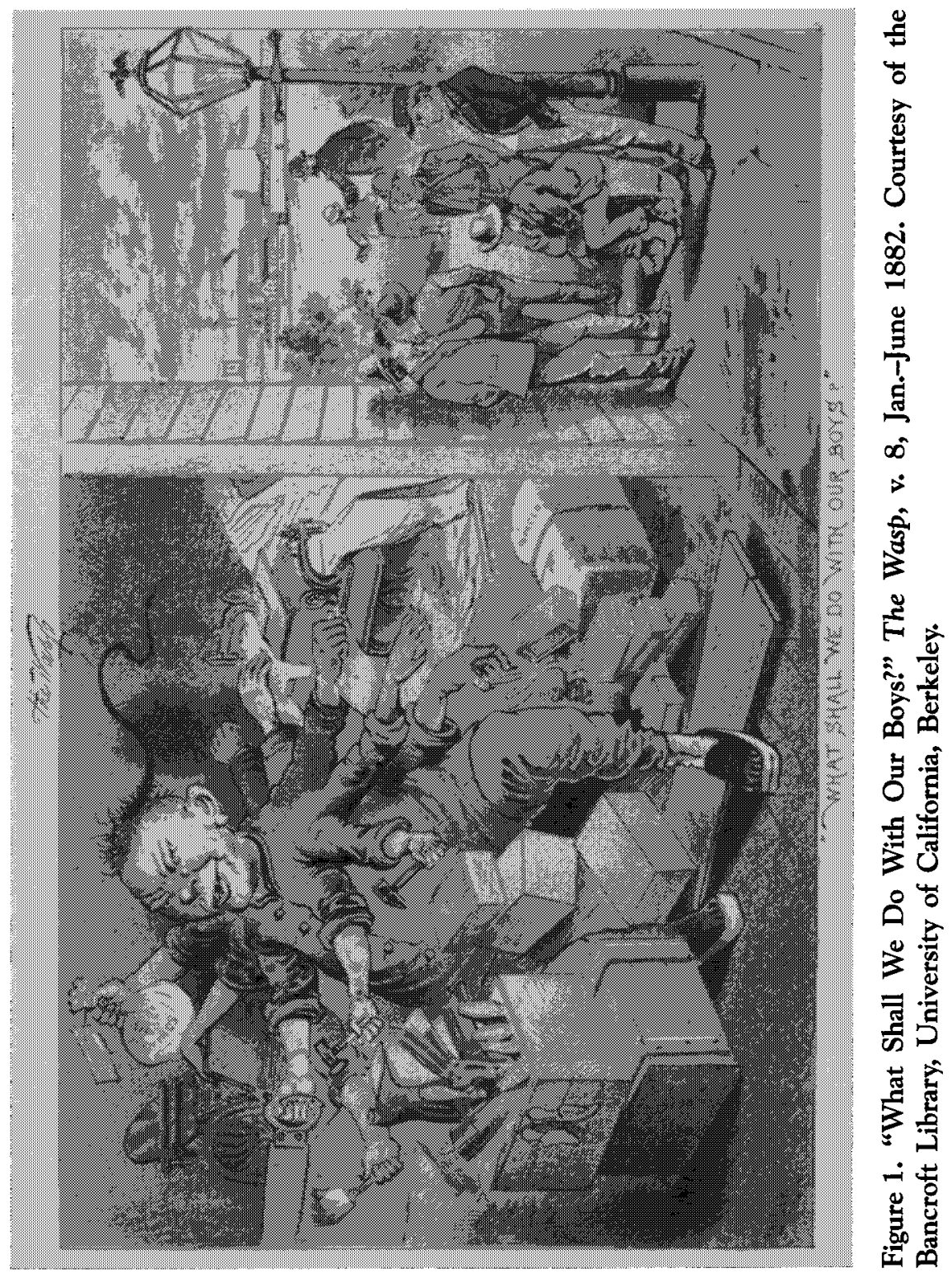
Once the 1880 Treaty was ratified, Congress enacted the first of the Chinese exclusion laws in 1882, which suspended the immigration of all Chinese laborers for the next ten years (Act of May 6, 1882, ch. 126, 22 Stat. 58). Chinese laborers already present in the United States, and nonlaborers, such as merchants, teachers, students, and travelers, were exempted from this exclusion. ${ }^{10}$ In order to allow those Chinese laborers who were already residing in the United States to leave and reenter the United States, the 1882 Act authorized the issuance of return certificates to Chinese laborers leaving the United States. The other exempt classes were required to obtain what came to be known as "Section 6" certificates. In 1884, Congress passed another law, strengthening the 1882 Act and clarifying that the exclusion applied to all Chinese laborers arriving from any foreign country, not just China (Act of July 5, 1884, ch. 220, 23 Stat. 115). The 1884 Act also specified that the identification certificates were the "only evidence permissible" to establish one's exempt status.

In 1888, Congress passed another law, known as the Scott Act, stating that all persons of "Chinese race," whether or not they were subjects of China, were prohibited from entering the United States unless they were of the exempt class with proper identification certificates (Act of September 13, 1888, ch. 1015, 25 Stat. 476). Most significantly, the 1888 Act prohibited the reentry of all Chinese laborers once they left the United States, regardless of whether they possessed a valid return certificate issued under the 1882 and 1884 Acts. These provisions clearly conflicted with the Burlingame Treaty and the Treaty of 1880 , which protected the rights of lawfully resident Chinese laborers to leave and reenter the United States at will. In 1892, Congress renewed the exclusion of Chinese for another ten years under the Geary Act, and required that all Chinese laborers lawfully present in the United States acquire a certificate of residence (Act of May 5, 1892, ch. 60, 27 Stat. 25). Congress subsequently renewed the exclusion two more times (Act of April 29, 1902, ch. 641, 32 Stat. 176; Act of April 27, 1904, ch. 1630, 33 Stat. 394, 428), and it was not until the Act of 1943, a wartime measure, that the Chinese exclusion laws were finally repealed (Act of December 17, 1943, ch. 344, 57 Stat. 600).

\section{B. Overview of Illegal Chinese Immigration}

While the exclusion laws did succeed in drastically reducing legal Chinese immigration into the United States, illegal Chinese immigration became

9. For a helpful summary of the Chinese exclusion laws, see Lee 2003, 43-46; Salyer $1995,17-32$.

10. Note that since persons born on U.S. soil, regardless of race, were U.S. citizens, as decided by U.S. '. Wong Kim Ark (1898), some Chinese were U.S. citizens by birth and not even the Chinese exclusion laws could interfere with their movement (see Salyer 1995, 98-100). Up until 1943, however, Chinese could not naturalize to become U.S. citizens (Lopez 1996, 45). 


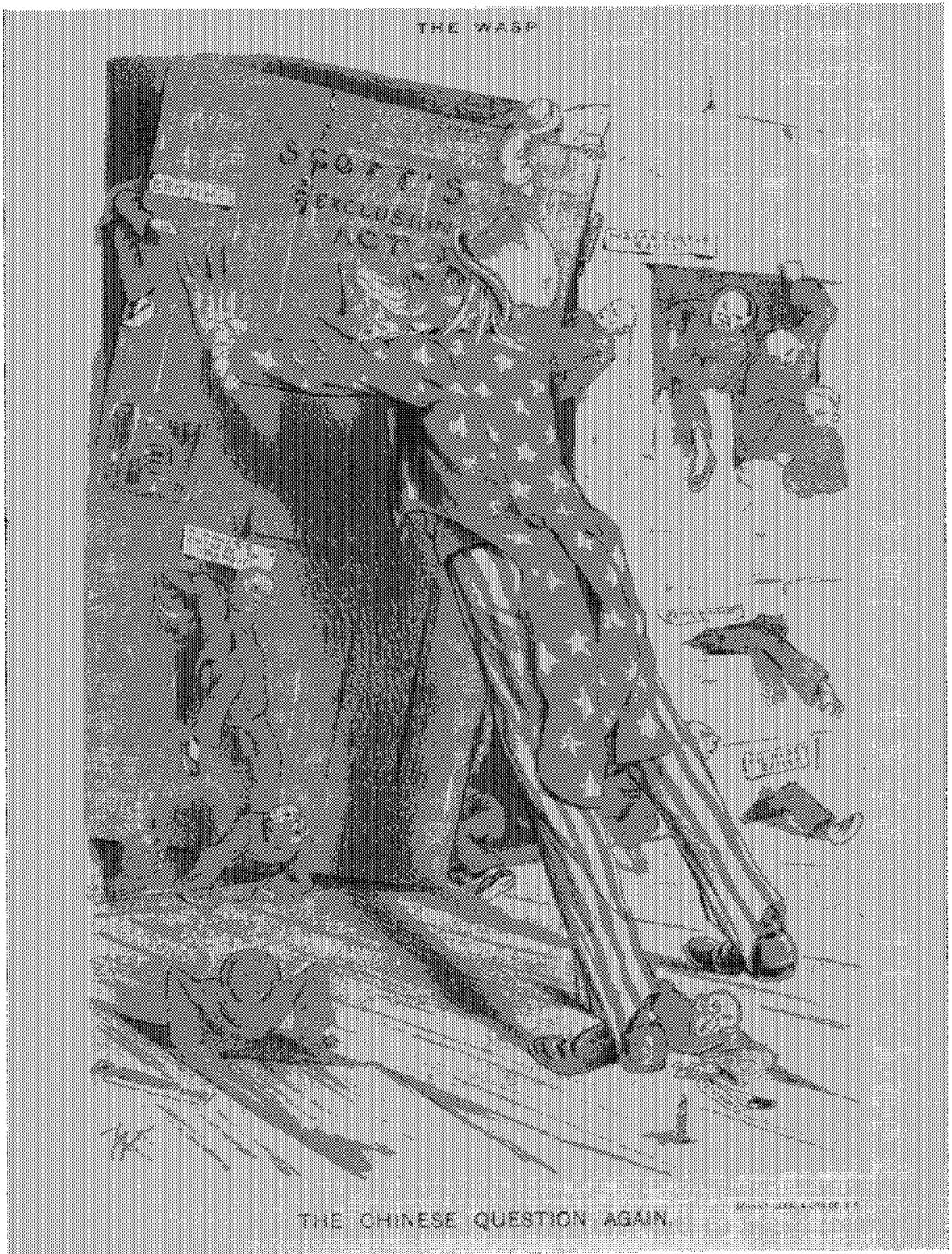

Figure 2. "The Chinese Question Again." The Wasp, v. 23, July-Dec. 1889. Courtesy of the Bancroft Library, University of California, Berkeley.

increasingly common during the exclusion era. Figure 2 depicts some of the different ways in which the Chinese became illegal immigrants. Chinese immigrants are shown "sneaking in" through gaps around the door labeled, "Canada," (top), and "Mexico" (bottom). But there were also other methods of illegal entry. Some of the other holes are labeled, for example, "habeas corpus route," "prior resident," "Chinese sailor," and "merchant fraud." I provide a brief overview of these different modes of illegal entry below. 
Categorized broadly, there were two principal types of strategies employed by Chinese immigrants to circumvent the exclusion laws. The first method relied on misrepresentation or the use of fraudulent immigration documents at designated ports of entry. In these cases, Chinese laborers would falsely claim to be native-born U.S. citizens. Others attempted to gain entry by falsely claiming to be laborers who had been in the United States before the exclusion laws were enacted, or members of an exempt class under the exclusion laws, such as merchants or minor sons of merchants. Chinese immigrants in these cases often faced long hours of intense and grueling questioning (see Hsu 1997). When their claims were denied, many filed a writ of habeas corpus to litigate their cases in federal courts (see Fritz 1988; Salyer 1995).

The second method of illegal entry involved evading official inspection altogether and entering the United States surreptitiously. Sometimes Chinese laborers came on small boats or as stowaways on large cargo vessels, either directly from China or through such places as Jamaica or Cuba, which exported a variety of agricultural products to the United States." Typically, a small group of Chinese or their smugglers would enter into an agreement with a seaman, offering to pay a fee in exchange for assistance in getting on the ship and avoiding detection throughout the long journey. ${ }^{12}$ Another possible method of clandestine entry was to become a seaman on a ship doing business at U.S. ports and to quietly slip away once the ship would dock. ${ }^{13}$ By far, however, the most common method of clandestine entry into the United States appears to have been through Canada and Mexico. Indeed, so many Chinese laborers entered the United States this way that it quickly became the focus of heated and sensationalized media and public attention (De Lorme 1973). The rest of this section takes up this mode of entry in greater detail.

\section{U.S.-Canadian and U.S.-Mexican Borders}

Many Chinese immigrants crossing the U.S.-Canadian border were laborers who had traveled to Canada years before in search of gold along the Fraser River in the 1850 s and 1860s, or immigrants who had come to build the Canadian Pacific Railroad in the 1870s; others had arrived to work in seasonal industries, such as fishing and logging (Con et al. 1982; Lai 1988).

11. See Letter from Baldwin, Immigration Inspector, to Commissioner General, Washington, D.C., Apr. 6, 1909, Part 1, roll 7, NAS; Letter from Acting Commissioner General, to Assistant Secretary, Feb. 25, 1921, Supplement, roll 4, NAS.

12. See Letter from James Bryan, Immigrant Inspector, New Orleans, LA, to Commissioner General of Immigration, Washington, D.C., Apr. 2, 1912, Part 1, roll 7, NAS; Letter from Baldwin, Immigration Inspector, to Commissioner General, Washington, D.C., Apr. 6, 1909, Part 1, roll 7, NAS.

13. It is also likely that in some cases, ship masters were bribed to hire the Chinese as crews and to permit them to escape upon landing. See Letter from Baldwin, Immigration Inspector, to Commissioner General, Washington, D.C., Apr. 6, 1909, Part 1, roll 7, NAS. 
These workers sought to enter the United States when they encountered difficulties finding work in Canada after the completion of the Pacific Railroad or due to downturns in the economy. The following exchange between an apprehended Chinese border crosser and an immigration officer found in an interview transcript among unpublished government records, illustrates this point well. In response to the immigrant inspector's question, "When you left China was it your intention to come to the United States as soon as an opportunity afforded itself?" the Chinese laborer replied, "At first, my intention was to go to Canada and afterwards I changed my mind because I couldn't find any work there." ${ }^{14}$ But there were also Chinese laborers who entered Canada with the sole purpose of making a surreptitious entry into the United States (see Ralph 1891).

A large portion of the illegal entry across the U.S.-Canadian border on the West Coast occurred along Puget Sound, Washington. Puget Sound was also a popular gateway for opium smuggling, and the same individuals and groups were often responsible for both opium and human smuggling (De Lorme 1973). On the East Coast, a popular gateway of entry was across the Niagara River into Buffalo, New York. In addition to the Niagara River, portions of the St. Lawrence River along the U.S.-Canadian border also constituted popular points of entry for Chinese border crossers. As described by one immigrant inspector, "There are a great many places all along that portion of the St. Lawrence River which forms a part of the boundary, where smuggling can be carried out." 15 Indeed, the boundary seemed so vast that he proceeded to declare, "when I look over this vast stretch of boundary line and think of the number of boats and the cordon of men that would be necessary actually to guard it as it should be guarded to keep Chinese from crossing, I become quite pessimistic as to what we may hope to accomplish."16

Similar to the history of Chinese immigration in Canada, many Chinese entered Mexico under labor contracts to work for the Mexican branch of the Southern Pacific Railroad Company or in other manual occupations (Craib 1996; Jacques 1974). Others entered with the sole purpose of crossing the border into the United States (Delgado 2004, 193). Indeed, immigration officials often suspected that Chinese laborers traveled to Mexico in order to cross the border into the United States. For example, one inspector in charge in San Diego made the following report about a ship carrying hundreds of Chinese laborers, which had entered a San Diego port en route to Guaymas, Mexico: "[Chinese passengers] are probably the vilest and filthiest lot that ever entered a United States port, and in view of the fact that they are

14. Transcript of Sworn Statements In the Matter of Chong Dick, Aug. 14, 1914, Part 1 , roll 30 , NAS.

15. Letter from A. Warner Parker, Special Immigrant Inspector, Montreal, Canada, to Commissioner General of Immigration, Washington, D.C., July 31, 1914, Part 1, roll 29, NAS.

16. Letter from A. Warner Parker, Special Immigrant Inspector, Montreal, Canada, to Commissioner General of Immigration, Washington, D.C., July 31, 1914, Part 1, roll 29, NAS. 
going to Mexico, not far from the American boundary line . . the majority of them will doubtless try to enter the United States at some time or other." ${ }^{17}$

Along the U.S.-Mexican boundary, Chinese immigrants crossed the border using a number of different methods of transportation. One common mode of transportation was via bonded freight cars entering the United States from Mexico. Bonded cars were sealed with U.S. customs seals and because immigration officers did not have the authority to break them, this method of border crossing became popular among smugglers. When enforcement on the railroad tightened, Chinese immigrants found a variety of other ways to cross the southern border. If there was enough water in the Rio Grande, they took small rowboats; if there were roads, pathways, highways, or mountain trails, they traveled by foot or hidden in carriages or cars (see generally U.S. Department of Commerce and Labor 1906, 13-15; U.S. Department of Labor 1916, xix-xx).

Once the Chinese crossed the border into the United States from either Canada or Mexico, they attempted to make their way deep into the interior as quickly as possible and to "blend in" with the rest of the resident Chinese population in order to avoid detection (see Perkins 1978, 11). A New York Times article (Sept. 12, 1909, p. SM13) written during this period noted, "All Chinamen, to paraphrase the old song, 'look alike,' and, once they gain the interior of the country, the quest for them makes the search for the proverbial needle in the haystack seem like a plausible and reasonable occupation." To avoid detection, some Chinese tried to "pass" as Mexicans since Mexicans were allowed to freely enter the United States during this period:

They [Chinese] come to Mexico with no intention to remain there but because they think they can enter the United States in an easy way. ... I found them to cut their pigtails and exchange their blue-jeans and their felt slippers to the most picturesque Mexican dress; that they learn to be able to say "Yo soy Mexicano"- "I am a Mexican," in case they should be held up by some American citizen while attempting to cross at a distant point from an Immigration Station. ${ }^{18}$

Other Chinese border crossers tried to disguise themselves as black. Figure 3 shows one of the many telegrams that inspectors from different immigration stations sent to each other upon receiving tips from railroad employees that suspicious Chinese were on board; in this telegram, an inspector from Michigan is alerting the immigration office in Chicago that, "A Chinaman blackened to represent Negro on Northwestern train arriving Chicago 7:35 tomorrow morning." ${ }^{\prime 19}$

17. Letter from Inspector in Charge, San Diego, CA, to Commissioner General of Immigration, Washington, D.C., May 10, 1907, Part 1, roll 9, NAS.

18. Letter from Marcus Braun, U.S. Immigration Inspector, New York, NY, to Frank P. Sargent, Commissioner General of Immigration, Washington, D.C., Feb. 12, 1907, Part 1, roll 12, NAS.

19. Telegram from Frank M. Jewell, Immigrant Inspector, Sault Ste. Marie, MI, to Immigration Service, Chicago, IL, Apr. 15, 1910, File 1/338, NAC. 


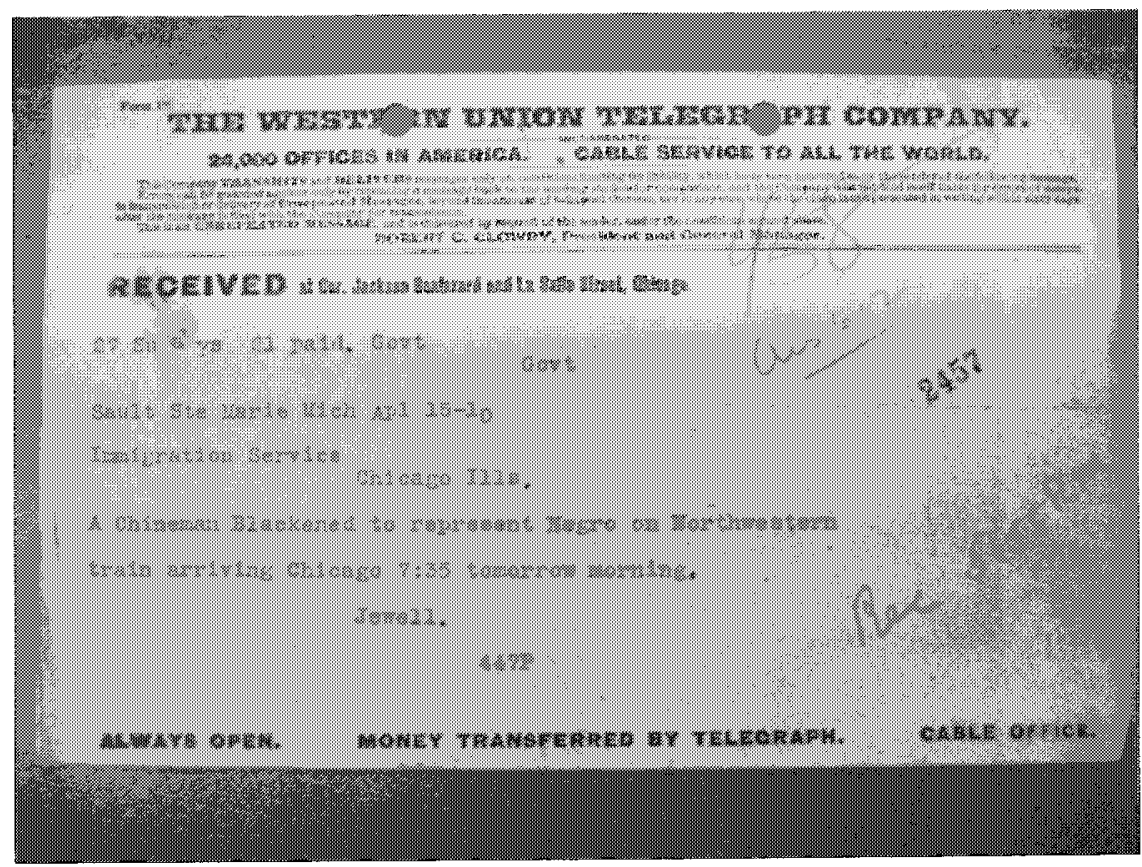

Figure 3. Telegram from Frank M. Jewell, Immigrant Inspector, Sault Ste. Marie, MI, to Immigration Service, Chicago, IL, Apr. 15, 1910; File 1/338; Correspondence of the Chinese Division, 1893-1924; Records of Immigration and Naturalization Service, Record Group 85; National Archives, Chicago, IL.

The process of making a journey into the interior often involved great hazards. Stories such as the following reported in the Los Angeles Times (Jan. 12, 1907, p. II1) were not uncommon: "How these Chinamen succeeded in getting into the United States is a story of frightful hardship. The immigration officials say that for a full month the five were locked in a freight car, and only for a little coarse food they carried with them they would have starved." Despite these accounts of hardship, however, there is also evidence that some illegal border crossers managed to make their way back to China to visit their homeland from time to time. In a letter dated February 28, 1911, for example, an immigrant inspector in Vancouver describes a young man named Tong Hee (see Figure 4), who traveled from Chicago to Vancouver "without American papers" and was apprehended. But he managed to escape and after having switched tickets with a Canadian Chinese, set sail to China. With the ticket he acquired from the Canadian Chinese, he was manifested outward as a Canadian Chinese, "thus enabling him to return to Canada without the payment of the head tax and later gain surreptitious entry to the United States."20

20. Letter from P. Robbins, Inspector in Charge, Vancouver, Canada, to P.L. Prentis, Immigrant Inspector in Charge, Chicago, IL, Feb. 28, 1911, File 1/383, NAC. 


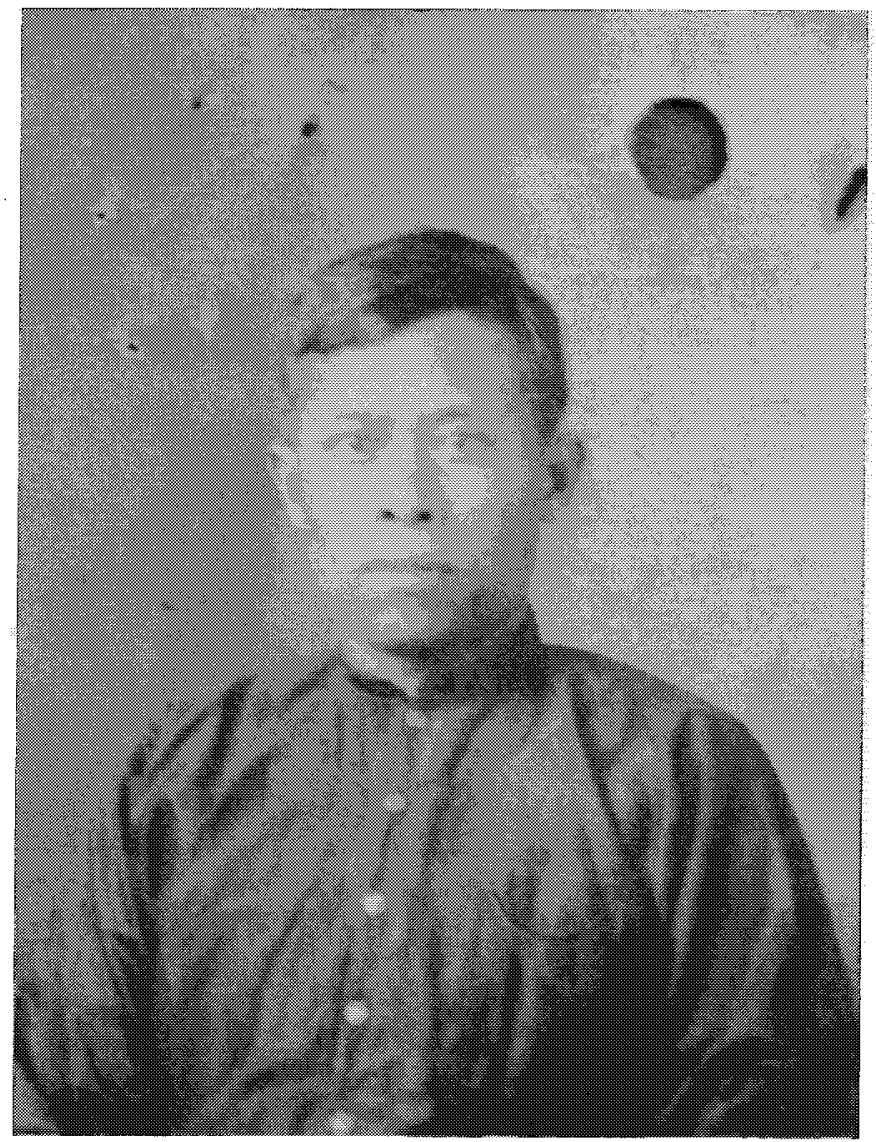

Figure 4. Photograph of Tong Hee, Feb. 28, 1911; File 1/383; Correspondence of the Chinese Division, 1893-1924; Records of Immigration and Naturalization Service, Record Group 85; National Archives, Chicago, IL.

\section{Government Response}

From the beginning, there were serious challenges to enforcing the exclusion laws. At the time of their enactment, the federal government had not yet created a separate agency devoted to the administration of immigration laws, and enforcement responsibilities fell to customs officials who were not well equipped to handle illegal Chinese immigration (Daniels 2004, 19-20). ${ }^{21}$

21. Up until 1903, enforcement of the Chinese exclusion laws was the responsibility of the Chinese Bureau within the U.S. Customs Service; in turn, the Chinese Bureau was only one of many divisions under the Collector's control. The Chinese Bureau not only lacked centralized and coordinated administration, it also had very little manpower. For example, in 1897 the San Francisco Chinese Bureau had a total of seven staff members: one inspector in charge, four inspectors, one interpreter, and one clerk (Salyer 1995, 38). The more centralized and expanded administrative center devoted to enforcing the immigration laws, the INS, was not created until 1933 (Daniels 2004, 26). 
Moreover, it was recognized early on that "Presidential orders and Departmental circulars and instructions of the Bureau of Immigration have no effect" on smugglers and illegal Chinese border crossers. ${ }^{22}$ Thus, it was left up to immigration officials in the field to implement creative strategies to counter the influx of Chinese border crossers. A popular technique developed by immigration officials was to inspect individual trains passing through wellknown gateway stations and to question all Chinese passengers on the train (see Perkins 1978, 16-17). Immigration inspectors in some regions were required to file "reports of daily employment," and many of these reports painstakingly recount such train inspections. ${ }^{23}$ One typical record excerpted below illustrates how the inspectors viewed all Chinese passengers as suspect:

I went on duty at 7:30 A.M. Handled correspondence and inspected night trains until 1:00 P.M., July 27th, when went off duty. Two Chinese arrived at Toledo off the LSAMS train from Cleveland, about 11 P.M., one being Woo Kee Hing, son of Woo Yuen Jock, a native-born, who works in his father's laundry... who did not have his papers but who is known to me. The other was Woo Hing, who exhibited certificate of identity No. 4924, merchant, Los Angeles, California . . . and claimed that he had been visiting in Cleveland a few weeks, intended to visit in Toledo a short time and then return to Cleveland. ${ }^{24}$

In 1892 , recognizing the difficulty of successfully excluding the Chinese at the border, the government shifted its focus to identifying and deporting illegal Chinese immigrants in the interior. ${ }^{25}$ The underlying logic was that illegal Chinese immigrants needed to be deported and that this would have a significant deterrent effect on potential border crossers. Under the Geary Act of 1892, Congress required all Chinese laborers lawfully present in the United States to acquire a certificate of residence. Moreover, immigrant inspectors were allowed to search Chinese businesses and residences without a warrant, as well as to stop and detain any Chinese they deemed "green" (Chinese who looked as if they had just crossed the border).$^{26}$ The following description of an arrest underscores the unfettered nature of this discretion:

22. Letter from Marcus Braun, Immigrant Inspector, New York, NY, to Frank P. Sargent, Commissioner General of Immigration, Washington, D.C., June 10, 1907, Part 1, roll 12, NAS.

23. It is not clear why and to what extent immigrant inspectors were required to submit daily employment records, since there are no records documenting the establishment of this program. But one possible reason for its establishment may have been to prevent immigrant inspectors from colluding with smugglers, and to ensure some level of accountability in the vast wilderness that made up the borderlands.

24. Report of Daily Employment by George R. Apple, Immigrant Inspector, Toledo, $\mathrm{OH}$, to Inspector in Charge, Immigration Service, Cleveland, OH, July 27, 1914, Part 1, roll 30, NAS.

25. Memorandum from Assistant Commissioner General, to Commissioner General, Oct. 27, 1913, Supplement, roll 2, NAS.

26. Letter from Samuel D. Dodds, Inspector in Charge, Buffalo, NY, to Harry R. Landis, Inspector in Charge, Buffalo, NY, Apr. 10, 1914, Part 1, roll 29, NAS. 
I met this Chinaman Ng Quong and as he looked "green" to me I asked him what documentary evidence he had showing his right to be in the United States... he had no papers so I placed him in jail overnight and the following morning, as soon as possible advised the Angel Island office, and requested the watchman there to advice $\mathrm{Mr}$ Edswell ... that I had a Chinaman whom I thought should be given a thorough investigation. ${ }^{27}$

In addition to these strategies, immigration officials attempted to implement, to varying degrees, a variety of other enforcement techniques. In some areas, they recruited private citizens and offered them monetary awards for information leading to the arrest of illegal border crossers (De Lorme 1973, 83). ${ }^{28}$ There were undercover agents (see Woo Wai v. United States 1915) and agents who pretended to be corrupt officials (see Sam Yick v. United States 1917) to try to expose suspected smugglers. ${ }^{29}$ Others advocated utilization of advanced technology. For example, at Puget Sound, Washington, "Fast maneuverable steam launches were placed in service late in the 1890s, and wireless telegraphic communications helped coordinate sea and land patrols" (De Lorme 1973, 88). When automobiles became widely available, they were used by immigrant inspectors to "visit the places where the greatest number of Chinese are employed ... to ascertain the right of different Chinese there employed to be and remain in the United States. ${ }^{30}$ In El Paso, the immigration service tried to implement a program of photographing all Chinese apprehended along the southern border for purposes of future cross-checking. ${ }^{31}$

However, as Lee $(2003,148)$ has pointed out, "State crackdowns regulate illegal immigration but do not end it. Rather, they merely change its location, form, size, cost, and structure" (see also Daniels 1986, 173; Smith 2000, 130). Thus, Chinese border crossings continued throughout much of the exclusion era, despite the increased border patrol, the use of improved technology, and other strategies developed to strengthen border enforcement. In 1927, for example, James Davis, the Secretary of Labor, declared, "If we had the whole

27. Letter from William H. Chadney, Immigrant Inspector, Monterey, CA, to Richard H. Taylor, Immigrant Inspector, Buffalo, NY, May 26, 1914, Part 1, roll 30, NAS.

28. See also Letter from J. Bryan, Immigrant Inspector, New Orleans, LA, to CommissionerGeneral of Immigration, Washington, D.C., Apr. 2, 1912, Part 1, roll 7, NAS; Letter from Luther C. Steward, Acting Supervising Inspector, San Antonio, TX, to Commissioner General of Immigration, Washington, D.C., Jan. 11, 1909, Part 1, roll 5, NAS.

29. See Letter from Thomas M. Ross, Inspector in Charge, Port Huron, MI, to P. L. Prentis, Inspector in Charge, Chicago, IL, Dec. 17, 1911, File 1/415, NAC.

30. Letter from William $\mathrm{H}$. Chadney, Immigrant Inspector, Monterey, CA, to Richard H. Taylor, Immigrant Inspector, Washington, D.C., Apr. 21, 1914, Part 1, roll 30, NAS.

31. Letter from U.S. Department of Labor, Immigration Bureau, to Supervising Inspector, El Paso, TX, Dec. 21, 1914, Part 1, roll 16, NAS. 
army guarding the Mexican and Canadian waterfront, we could not stop this invasion by infiltration" (New York Times, June 19, 1927, p. 9).

\section{EXPLAINING WIDESPREAD NONCOMPLIANCE}

What explains the failure of Chinese exclusion laws? The typical view is that economic calculations motivated the illegal migration of Chinese laborers into the United States during the exclusion era. That is, Chinese laborers came because they had much to gain from their illegal entry (better jobs and better wages), but little to lose since they faced only a relatively small risk of apprehension. And even if apprehended, many of them expected to be sent back to Canada or Mexico, where they could simply try again. This view, which effectively reduces Chinese laborers to simple rational choice actors, however, overlooks other important social factors that may have enabled and facilitated illegal Chinese border crossings during the exclusion era. In particular, I suggest that normative values and opportunity structures also played an important role in generating this pattern of mass defiance. Specifically, with respect to normative values, widespread belief among the Chinese that the exclusion laws lacked social and moral legitimacy likely facilitated their willingness to violate the exclusion laws. In terms of opportunity structures, the existence of well-organized and powerful smuggling networks, and liberal immigration policies of Canada and Mexico provided an environment in which thousands of Chinese laborers found themselves in a favorable position to defy the exclusion laws. I examine each of these factors in turn below.

\section{A. Normative Values}

There is very little empirical data that documents illegal Chinese border crossings from the perspective of the border crossers themselves (for a rare exception, see Shone 1989). Their conspicuous silence is not surprising given that their very existence was shrouded in illegality and they were forced to lead "shadowed lives" at the margins of society (Chavez 1998). Thus, there is no direct evidence that we can use to examine their attitude toward the exclusion laws. However, we can infer what their attitudes must have been from what we know about the prevailing attitudes of the general Chinese and Chinese American communities at the time. In addition, court cases filed by Chinese border crossers to protest their treatment after their apprehension constitute another important source of data that sheds light on their attitude toward the exclusion laws. Of course, neither body of evidence "proves" a causal link between these normative values and their decision to defy the exclusion laws. However, these attitudes are wholly consistent with, 
and generally supportive of, past findings on the significance of normative values in explaining law-abiding behavior.

\section{Chinese Attitude Toward the Exclusion Laws}

As described by Schatkin, Sussman, and Yarbrough $(1955,46)$, "The Chinese resented the Exclusion Act very much and did everything in their power to circumvent it. They considered the Act evil, and anything they could do to overcome such evil was proper. In fact, an honest Chinese, otherwise ethical in his personal and business transactions, would not hesitate to use fraudulent means to enable an alien Chinese to enter the United States." To understand the nature and depth of resentment that the Chinese felt toward the exclusion laws, it is helpful to first consider the early Chinese American experience in the United States in the years before the enactment of the 1882 Chinese Exclusion Act. Within the first few years of their arrival in the 1850s, Chinese immigrants in the United States became targets of not only extreme racial hostility and violent attacks, but also numerous types of discriminatory laws that singled them out at the local and state level. According to Charles McClain, as early as 1852, Chinese immigrants faced discrimination in many areas of law, including state and local tax laws, city ordinances regulating businesses, occupational licensing requirements, as well as criminal laws and procedures (McClain 1984, 1994; McClain and McClain 1991). However, "Far from being passive or docile in the face of official mistreatment, they [the Chinese] reacted with indignation to it and more often than not sought redress in the courts" (McClain 1994, 3). They also wrote letters to their government in China, protesting their mistreatment (Zo 1978, 181).

Given these past struggles, Chinese immigrants were painfully aware that the American legal system was not impervious to racial hostilities and prejudice. Moreover, individual and community resistance to discriminatory laws were not new to Chinese immigrants by the time the U.S. government began enacting Chinese exclusion laws in the 1880s. Though the Chinese government and Chinese immigrants in the United States were unable to prevent the passage of the exclusion laws, there was a widespread perception among the Chinese (both in China and in the United States) from the outset that the laws were extremely unfair and discriminatory. In particular, the centrality of race and racism apparent in the Chinese exclusion laws was not lost on the Chinese. For example, Oscar Greenhalge, a Secret Service agent, "reported meeting an unidentified Chinese woman... [who] '... declared herself against the Chinese Exclosion [sic] Laws, sai[d] the Chinese had as much right to land in America as the Irish, who were always drunk and fighting"' (quoted in Salyer 1995, 43).

Chinese diplomats and elites were also vocal about their opposition to the exclusion laws in their writings and speeches. Chinese officials, in their 
letters to the U.S. State Department, complained that various provisions in the exclusion laws were a violation of the 1880 Treaty between the United States and China, and that they were clearly discriminatory since they did not apply to any other immigrants in the United States (Tsai 1970, 215216; Tsai 1986, 65). The following excerpt from an article published in the United States by a Chinese foreign minister, Wu Tingfang, reveals the intensity of such resentment felt by the Chinese (Wong 1998, 10):

Justice would seem to demand equal consideration for the Chinese on the part of the United States. China does not ask for special favors. All she wants is enjoyment of the same privileges accorded other nationalities. Instead, she is singled out for discrimination and made the subject of hostile legislation. Her door is wide open to the people of the United States, but their door is slammed in the face of her people.... If they think it desirable to keep out the objectionable class of Chinese, by all means let them do so. Let them make their immigration laws strict as possible, but let them be applicable to all foreigners.

Chinese immigrants were also not afraid to express a sense of betrayal at the hypocrisy that was apparent in the exclusion laws:

The laws of this country deny to Chinese alone, the rights of citizenship and even the right of fair treatment. . . The official action of the United States Government in its treatment of Chinese turns back the centuries and seems to draw its inspiration from the practices of the dark ages. It is not the treatment which the civilized twentieth century expects; and it is curious that this country resorts to methods of exclusiveness against which this very country complained of China in its last century. ${ }^{32}$

As the exclusion laws became increasingly more restrictive over the years, Chinese attitudes toward the exclusion laws became more openly resistant. For example, when the Geary Act was enacted in 1892, Chinese American organizations mobilized the community to angrily denounce the legislation and to call for a community-wide defiance. Under the Geary Act, all Chinese laborers entitled to be in the United States were required to apply for a certificate of residence that would function as prima facie evidence of their legal right to reside in the United States. Any Chinese laborer failing to present a certificate of residence could be arrested and placed under summary deportation proceedings. The reaction of the Chinese community in the United States to the Geary Act was angry and swift. The Chinese viceconsul in San Francisco, for example, charged that the law placed Chinese "on the level of ... dogs" (quoted in Salyer 1995, 46). The Chinese Six Companies, one of the most prominent and well organized community associations

32. Petition from Chinese merchants, Portland, $O R$, to Chen Tung Liang Chong, Envoy Extraordinary to the United States, circa 1904, Part 1, roll 12, NAS. 
representing Chinese Americans, declared in a written proclamation posted throughout San Francisco, "[The Geary Act] is an unjust law and no Chinese should obey it. The law degrades the Chinese and if obeyed will put them lower than the meanest of people. It is a cruel law. It is a bad law. ... [S]ee how mean and contemptible it wants to make the Chinese" (McClain 1994, 204). These campaigns had a powerful effect; by the time the case challenging the constitutionality of the Geary Act reached the U.S. Supreme Court in May of 1893 (Fong Yue Ting थ. United States 1893), only some 13,000 Chinese had registered while more than 90,000 still had not (Daniels 2004, 21-22).

Resentment against the exclusion laws was prevalent not only among Chinese Americans, but also among the Chinese in China, which was not surprising given that they were the ultimate targets of the Chinese exclusion laws. The 1905 anti-American boycott, which began on May 4, 1905, when the Shanghai Chamber of Commerce passed a resolution boycotting American goods, is a prime example illustrating the strength and prevalence of the growing resentment in China against the Chinese exclusion laws. The 1905 boycott was partly fueled by the extension of the exclusion laws to cover the Chinese in Hawaii and the Philippines, two territories that had been newly annexed by the United States in 1898 (Tsai 1970, 292). But more generally, the 1905 boycott was an "emotional outburst" brought about by the "humiliation and anger, defeats and frustration" that the Chinese had experienced since the second half of the nineteenth century (Tsai 1970,292). As such, the anti-American boycott was not only a commercial affair, but a much broader cultural movement of protest against discriminatory American policies (see Chen 2000: 148-161; Kiong 2002; Wang 2001).

In the context of the deep and pervasive sense of resentment felt by the Chinese against American immigration policies, it should come as no surprise that so many Chinese laborers were willing to circumvent the exclusion laws. As Betty Sung $(1967,96)$ points out, "To the Chinese way of thinking ... no moral issue was involved here. The exclusion laws were discriminatory and unjust. . . . The gates of the United States were open freely to everyone, and she proclaimed herself a haven for the poor and oppressed. Then why were the Chinese the only people to be denied entry? It did not make sense to a logical mind, but instead of belligerent opposition, the Chinese resorted to nonviolent disobedience."

\section{Chinese Border Crossing Cases in U.S. Courts}

Chinese border crossers who were apprehended by immigrant inspectors sometimes turned to the U.S. federal courts to challenge various aspects of the enforcement procedure or even the designation of their status as unlawful aliens. These cases (hereinafter "Chinese border crossing cases") constitute another body of evidence, albeit indirect, that the exclusion laws were viewed 
by the Chinese (this time more specifically, Chinese border crossers themselves) as not worthy of respect. ${ }^{33}$ Though there is no clear evidence indicating precisely how these Chinese were able to obtain lawyers to navigate the American legal system, it is likely that they were represented by lawyers hired by Chinese community associations, such as the Chinese Six Companies. ${ }^{34}$ Regardless of how these Chinese came to be represented by counsel or who specifically represented them in court, there is an unmistakable undercurrent that runs through all of these cases-a sense of bold and almost determined defiance, consistent with the proposition that Chinese border crossers viewed the exclusion laws as immoral and unworthy of obedience. In exasperation, the court in United States v. Yuen Pak Sune $(1910,263)$ declared, "Chinese aliens are now coming in droves and in groups to various points on the border and crossing into the United States. They make no pretence of going to the ports of entry. They openly violate and designedly disregard the law."

Instead of admitting wrongdoing and quietly acquiescing to deportation procedures, many apprehended Chinese border crossers made claims to U.S. citizenship and sometimes also protested one aspect or another of the administrative process in which they were entangled. The courts, however, appear to have relied heavily on the "presumption that a person of Mongolian race is not a citizen" and furthermore, that this presumption was "materially strengthened" when the Chinese were apprehended seeking to enter the country in a clandestine manner (Lee Lew You v. United States 1916; see also United States v. Hom Young 1912; Sit Sing Kum v. United States 1921; Chin Lund v. United States 1925; Yee Yet v. United States 1910). Thus, for example, in United States $v$. Chung Fung Sun $(1894,262)$, the district court in New York considered Chung Fung Sun's claim that he was a U.S. citizen by virtue of his birth in the United States but concluded that "the improbability of the story must be apparent to all." The court emphasized, "There is presumptive evidence that the appellant, and five other Chinamen, came here from Canada, having been smuggled at night across the border at an unfrequented spot near Plattsburgh, N.Y. There is also proof that the appellant's admissions that he never had been in the United States before and that the theory of his having a father in this country was an afterthought

33. The cases discussed in this section include not only those cases in which there was no dispute that the Chinese litigants were apprehended in the act of surreptitiously crossing the horder, but also those cases in which the government made such a claim and it played a central role in the outcome of the case. I do not discuss the relatively large number of cases involving the prosecution of Chinese smugglers.

34. Historical accounts show that from very early on, Chinese immigrants in the United States were able to mobilize community resources to challenge anti-Chinese legislation and discriminatory practices (Daniels 2004, 23; Lee 2003, 139-141; Ma 1991, 163; McClain 1994, $14-15)$. It is likely that a similar type of community mobilization was at work in the Chinese
border crossing cases. 
invented to fit the exigencies of the situation" (United States v. Chung Fung Sun 1894, 262).

Chinese border crossers also raised a variety of issues pertaining to procedural fairness, including questions about whether deportation proceedings were criminal or civil in nature (United States v. Hung Chang 1904), whether they had a right to counsel (Wong Back Sue v. Connell 1916), whether proper rules of evidence had been followed (Guan Lee v. United States 1912), and whether proper jurisdiction had been exercised in their cases (see, e.g., Chow Chok v. United States 1908; Toy Tong v. United States 1906; United States v. Jew Lee 1926). In Jung See v. United States (1925), for example, a thirtyfive-year-old Chinese man who was apprehended in Detroit, Michigan, admitted that he was born in China and that he had entered the United States surreptitiously from Vancouver, Canada, but he also claimed that his father had been born in the United States, making him a U.S. citizen. The immigrant inspector, however, issued an order of deportation, which was affirmed by the Board of Review, an agency within the Department of Labor. Before the Eighth Circuit Court, Jung See argued, inter alia, that he should have received a judicial, rather than an administrative, hearing on the question of his claim to citizenship. The Eighth Circuit, however, ruled against Jung See, holding that he had no right to a judicial hearing on his claim of U.S. citizenship, and that the decision of the Department of Labor was final and conclusive.

The thorniest issue presented in the Chinese border crossing cases was determining to where the apprehended Chinese should be sent back. Up until 1892, the Chinese exclusion laws had required that all Chinese who were unlawfully present in the United States "shall be removed from the United States to the country whence he came" (Act of May 6, 1882, ch. 126, 22 Stat. 58, §12; Act of July 5, 1884, ch. 220, 23 Stat. 115, §12; Act of September 13, 1888, ch. 1015, 25 Stat. 476, \$13). The 1892 Chinese Exclusion Act, however, held that such persons "shall be removed from the United States to China," unless they could show that they were "subjects or citizens of some other country" (Act of May 5, 1892, ch. 60, 27 Stat. $25, \S 2$ ). This did not put the matter to rest, however, as the general immigration law enacted in 1907 contained conflicting provisions (Act of February 20, 1907, ch. 1134, 34 Stat. 898, $\$ \$ 21,35,36)$. Thus, some Chinese border crossers argued that because they had "come from" Mexico or Canada, those were the countries to which they should be deported (see, e.g., In re Leo Hem Bow 1891; United States ex rel. Hen Lee v. Sisson 1916; Wallis v. United States 1916).

The courts, however, were often weary of such arguments, because it was widely acknowledged that deportation to Canada or Mexico simply led to repeated attempts to cross the border (see, e.g., Lui Lum v. United States 1909). On the other hand, the courts were also aware that some Chinese crossed the border into the United States in the hopes of securing a free trip back to China for purposes of visit or moving back (Perkins 1978, 26; 
see also In re Leo Hem Bow 1891). ${ }^{35}$ Additionally, some Chinese found to have illegally crossed the border into the United States could not be ordered back into Canada because they could not afford to pay the Canadian head $\operatorname{tax},{ }^{36}$ and U.S. marshals were not authorized to pay the tax on behalf of such Chinese (United States v. Ah Toy 1891). As a result of these varying considerations and circumstances, cases often reached inconsistent and conflicting results (see, e.g., In re Mah Wong Gee 1891; United States ex rel. Haum Pon ข. Sisson 1916; but see United States v. Wong You 1912; Lee Sim v. United States 1914).

While these acts of defiance on the part of Chinese border crossers in U.S. courts do not definitively show that Chinese border crossers viewed the exclusion laws as lacking in moral legitimacy, what is evident from these cases is that Chinese border crossers were willing to challenge their presumed illegal status and to mobilize the exclusion laws to their advantage, even as the facts of their case showed that they had been caught in the physical act of crossing the border. From this, it would seem but a small inferential leap to assume that the border crossers viewed the exclusion policy as not worthy of respect or obedience.

\section{B. Opportunity Structures for Noncompliance}

\section{Smuggling Networks}

Whether they were trying to cross the U.S.-Canadian or the U.S.Mexican border, most Chinese border crossers generally relied on professional smugglers and guides to take them across the border rather than attempting to cross on their own (see Los Angeles Times, May 31, 1894, p. 7; Los Angeles Times, Aug. 14, 1901, p. 10; New York Times, May 17, 1925, p. 12). Chinese tongs or secret societies, as well as individual Chinese businessmen, were involved in smuggling operations (Farrar 1972, 19-22; Ma 1991, 164). Many of these smuggling operations were well organized with knowledgeable local residents at their disposal in China, Canada, Mexico, and the United States. As described in one government report, for example, "all through northern Mexico, along the lines of railroad, are located so-called boarding houses and restaurants, which are the rendezvous of the Chinese and their smugglers" (U.S. Department of Commerce and Labor 1906, 13).

35. See also Letter from R. H. Taylor, Immigrant Inspector, Tucson, AZ, to CommissionerGeneral, Washington, D.C., May 19, 1910, Part 1, roll 16, NAS.

36. After 1885 , Chinese wanting to enter Canada were required to pay a head tax, as discussed in the next section describing the immigration policies of Canada. Once the head tax was paid, the Canadian government would issue a certificate entitling the Chinese to leave and reenter Canada without further payment. Some Chinese who purportedly crossed the border from Canada lacked this certificate for one reason or another. 
These smuggling networks served three critical functions in enabling the Chinese to circumvent the exclusion laws. First, they established effective channels through which Chinese immigrants in the United States could communicate with their family members and friends in China, and to arrange for their travel to the United States. Often, the first step in the illegal border crossing process involved a Chinese immigrant in the United States contacting one of the smuggling leaders in the local area and vouching to pay for the safe passage of his friend or relative from China. The smuggler would then contact his agent in China, who would make arrangements for the friend or relative to travel to the United States (Perkins 1978, 12) ${ }^{37}$ In other instances, smugglers functioned as middlemen between U.S. employers and Chinese laborers arriving in Mexico, serving as an important source of information flow between the parties. ${ }^{38}$

Second, smugglers provided invaluable "coaching tips" and instructions to the would-be Chinese border crossers on how to dress and speak so as to avoid detection. As illustrated in the following excerpt found in a letter written by one of the immigrant inspectors in Detroit to another inspector in Chicago, the ability of a border crosser to "blend in" with local Chinese residents was critical in making his journey a success:

We have recently had information that Chinese smuggled into this country from Canada ... were destined for Chicago ... if you ever see these Chinamen conducted through by the smugglers arrest them on sight. There is no doubt but that you would be able to distinguish these new-comers. . . . This winter all the Chinamen whom we have caughtand there have been quite a few of them-have been most invariably dressed with caps, heavy rubbers or arctics, and overcoats, such as you would not see a Chicago Chinaman wearing. ${ }^{39}$

Thus, smuggling operations played a critical role in "Americanizing" the Chinese even before they ever set foot in the United States. According to an account told by one immigration inspector, the "Americanization" process for the would-be border crossers began in China and continued throughout the long journey (Perkins 1978, 12):

An alien brought in by the Six Companies was given preliminary instruction in English and deportment in China, after which arrangements would be made for him to be taken to Mexico.... On arrival,

37. See also Letter from Oscar Greenhalge to Walter $S$. Chance, Supervising Special Agent, Treasury Department, Washington, D.C., Jan. 30, 1899, Part 1, roll 20, NAS; Letter from Henry P. Coffins, American Consul at Mazatlan, Sinaloa, Mexico to The Honorable Secretary of State, Washington, D.C., Jan. 28, 1910, Part 1, roll 9, NAS.

38. Letter from Marcus Braun, U.S. Immigration Inspector, New York, NY, to Frank P. Sargent, Commissioner General of Immigration, Washington, D.C., Feb. 12, 1907, Part 1, roll 12, NAS.

39. Letter from Chinese Inspector in Charge, Detroit, MI, to L. T. Plummer, Chinese Inspector in Charge, Chicago, IL, Mar. 31, 1904, File 1/81, NAC. 
he would be met at the docks by a Company agent who would take him in tow and see that he was put to work in a restaurant or laundry. There he could be weaned further away from some of his Chinese mannerisms.... When his indoctrination was completed, he would be put on the train for Nogales, Sonora. From that city he would travel by stage to Naco, Agua Prieta or possibly Mexicali. There he would be turned over to a Mexican hired to take him across the border and deliver him to a contact in some nearby American town. In the United States his Americanization was continued.

Finally, smuggling networks offered Chinese border crossers the physical means of transportation necessary to gain entry into the United States. The following description of a smuggling operation provided to an immigrant inspector by one of his informants illustrates a typical trip taken by a Chinese laborer to enter the United States from Canada via Niagara River:

This [smuggling] combination has been using the following system; The Chinese are smuggled across the Niagara River when few people are on the streets and placed on the cellar of the Baker home, 57 Delevan Ave., Buffalo, where they are kept for a time, until such time they can take arrangements to put the Chinese aboard a train, exact route unknown to informant. The Chinamen are dressed in some of the mother's old clothes and Addie and Leola Baker each take a Chinaman by the arm and escort them to an automobile waiting in front of the door. This auto is kept on the other side of the street until such time as they are ready to make a quick get away. ${ }^{40}$

As smuggling networks grew, immigration officials also became increasingly focused on arresting and prosecuting smugglers (Los Angeles Times, June 18, 1911 , p. II8; U.S. Department of Labor 1918, 32). ${ }^{41}$ Many smuggling networks, however, had considerable economic and political clout, ${ }^{42}$ in stark contrast to the fledgling resource base of local immigration offices (see generally Kim and Markov 1983). One smuggling operation in Buffalo, New York, for example, was described in the following way by an inspector in 1913:

[As] Opposed to [the smuggling networks] the Government has three or four men, working out of two offices; their inspectors in charge have dozens of other things besides Chinese smuggling to look after ... they

40. Letter from Samuel D. Dodds, Chinese Inspector, to Harry R. Landis, Inspector in Charge, Buffalo, NY, Apr. 14, 1914, Part 1, roll 29, NAS.

41. Memorandum from Richard H. Taylor, Immigrant Inspector, to Bureau of Immigration, Washington, D.C., Jan. 11, 1915, Part 1, roll 30, NAS.

42. Letter from Edward P. Mores, Immigrant Inspector, Santa Ana, CA, to Inspector in Charge, Immigration Service, Los Angeles, CA, Aug. 1, 1914, Part 1, roll 30, NAS; Letter from Inspector in Charge, San Diego, CA, to Inspector in Charge, Los Angeles, CA, May 16, 1914, Part 1, roll 28, NAS; New York Times, May 17, 1925, p. X12. 
have no equipment; they have no money to spend; they have to wait two or three months to be reimbursed for their actual expenses; they work at the circumference of a great circle, while the smugglers, who know what they want to do and where they want to go and when, are at the center of that circle. ${ }^{43}$

Much of the smuggling networks' clout was built upon the lucrative nature of their business. By 1909, the Galveston Tribune (Nov. 25, 1909) was reporting that smugglers were collecting as much as $\$ 500$ to $\$ 1,000$ for each Chinese immigrant successfully crossing the border from Mexico. And given the possibility of large profits in the smuggling business, official government corruption became prevalent, which lent even greater security to the business and ensured greater chances of a successful journey for Chinese border crossers. ${ }^{44}$ For example, according to Thomas Scharf, an immigrant inspector who eventually resigned from his post, citing "disgust" at the government's complicity in the Chinese smuggling business: "I have run against railroad and Chinese money at every turn. Attempts have been made to bribe and frighten me. I have been offered money on one side and on the other have been warned that if I persisted in trying to enforce the law I would be accused and dismissed from my place" (New York Times, Oct. 14, 1897, p. 1). He called the Chinese exclusion laws a "farce" (see also New York Times, Aug. 25, 1907, p. 8; Los Angeles Times, Jan. 25, 1905, p. II2).

\section{Immigration Policies in Canada and Mexico}

Another important set of opportunity structures that enabled illegal Chinese border crossings during the exclusion era is the immigration policies of Canada and Mexico, which stood in direct opposition to U.S. immigration policy. Specifically, Canada and Mexico were in much need of cheap labor and did not exclude Chinese immigrants until the 1920s and 1930s, respectively. Given the numerous points of clandestine entry available along the vast U.S-Canadian and U.S.-Mexican borders, the liberal immigration policies of Canada and Mexico placed thousands of Chinese in a favorable position to cross the border if they wished to do so.

The first wave of Chinese laborers arrived in Canada in the late $1850 \mathrm{~s}$ as indentured servants or in search of gold on the Fraser River. The second wave of Chinese immigration began in 1880 when over 15,000 Chinese laborers entered Canada in order to work on the Canadian Pacific Railway,

43. Letter from Harry R. Landis, Inspector in Charge, Buffalo, NY, to Commissioner of Immigration, Montreal, Canada, Dec. 14, 1913, Supplement, roll 2, NAS.

44. See P. L. Prentis, Inspector in Charge, Chicago, IL, to Commissioner General of Immigration, Washington, D.C., Dec. 5, 1911, File 1/ 415, NAC. 
which was completed in 1885 (Con et al. 1982, 13-24; Scheinberg 1994, 26; Lai 1988, 31; Chan 1982, 520-21). Up until 1885, Chinese immigrants enjoyed a period of unrestricted entry due to Canada's high demand for cheap labor. In 1882, for example, the Canadian Pacific Railway contractor informed the Canadian prime minister that "many industries that are now in operation could not be made profitable without Chinese labor and many industries are underdeveloped, for want of more Chinese" (Wai-man 1984, 97).

As in the United States, however, Chinese immigrants in Canada faced widespread racial hostilities and discrimination (Roy 1976; Daniels 1986; Baureiss 1987). In 1885, the Canadian government caved in to the growing anti-Chinese sentiments and passed the Chinese Immigration Act, which imposed a $\$ 50$ head tax on each Chinese immigrant entering the country. This head tax was raised to $\$ 100$ in 1900 , then again to $\$ 500$ in 1903 (Scheinberg 1994, 27). Though these head taxes did initially curb the flow of Chinese immigration into Canada, after a few years it became clear that it was relatively ineffective in deterring Chinese immigration (Con et al. 1982, 83-84; Lai 1988, 52, 58-59). It was not until 1923 that Canada finally followed the American example and imposed an absolute bar on the entry of all Chinese laborers; the exclusion lasted until 1947 (Bangarth 2003, 395).

Enforcement of the Chinese exclusion laws in the United States also depended on Mexico closing its doors to Chinese immigrants, as pointed out by Marcus Braun, a well-known immigrant inspector: "As long as Mexico has no laws on her statute books which are at least half way in concert with our own immigration laws, the smuggling of immigrants will continue, because it is obvious that the policing of 2000 miles of border line is probably impossible. ${ }^{45}$ Braun also recognized, however, that Mexico was not to going to adopt restrictive policies, at least not in the early 1900s when there was a critical need for cheap labor in Mexico: "Mexico does not want to lose any of its labor, even though it may be temporary, because they need every pair of working hands they can get." ${ }^{, 46}$

Chinese immigration into Mexico began as early as 1635 , but it was not until the late 1800 s that the Chinese began to immigrate in mass numbers (Hu-Dehart 1982). With the rise of General Porfiro Díaz to power in 1876, Mexico embarked on an ambitious national economic expansion. As part of that policy, Mexico signed a Treaty of Amity and Commerce with China

45. Report from Marcus Braun, Immigrant Inspector, New York, NY, to Frank P. Sargent, Commissioner General of Immigration, Washington, D.C., Feb. 12, 1907, Part 1, roll 12, NAS. 46. Report from Marcus Braun, Immigrant Inspector, New York, NY, to Frank P. Sargent, Commissioner General of Immigration, Washington, D.C., Feb. 12, 1907, Part 1, roll 12, NAS. Though Congress had not initially considered the importance of Mexican cooperation when it first enacted the Chinese Exclusion Act of 1882, it did subsequently engage in attempts to induce the Mexican government to adopt more restrictive immigration laws and to allow U.S. immigration inspectors to cross the border to apprehend the Chinese attempting to cross the border (Cott 1987). 
in 1899, which granted each nation most-favored-nation status (Cott 1987, 69). Under this Treaty, trade and immigration between the two countries were to remain unrestricted. Similar to their counterparts in the United States and Canada, the Chinese in Mexico helped to build the Southern Pacific Railroad. They also worked as miners, ranchers, and railroad employees, and over time, they began to thrive as small business owners in Mexico. But as in the United States, their economic success eventually stirred extreme resentment among Mexicans, who came to see the Chinese as depriving them of their jobs and economic opportunities. As a result, Chinese immigrants became frequent targets of violent mob attacks in the early 1900s (Hu-DeHart 1980; Curtis 1995). In regions where the Chinese immigrant population was substantial, as in Sonora, a variety of discriminatory ordinances were enacted to oppress and intimidate the Chinese business community (Hu-DeHart 1980).

Though Mexico never enacted Chinese exclusion laws similar to the ones found in the United States and Canada, it did adopt a general immigration law in 1908 against immigrants with disease, which was widely understood as having the aim of restricting Chinese immigration (Craib 1996, 23-24). This law, however, had no lasting impact on Chinese immigration into Mexico. In his annual report on Mexico in 1909, a British officer in Mexico reported (quoted in Craib 1996, 24):

[T]here do not appear to have been any difficulties such as occurred in the preceding year in regard to the immigration of Japanese and Chinese Coolies into Mexico... [the] Chinese still arrive in large quantities and undoubtedly considerable numbers of them still succeed in making their way across the frontier into the United States.

On the other hand, in those Mexican states with significant Chinese populations, racial attacks and discriminatory laws turned into extremely violent and harsh expulsion campaigns in the 1930s. In Sonora, Mexico, for example, a 1931 order issued by the governor forced the Chinese to liquidate their holdings and leave the state within a very short period of time (Hu-DeHart 1982; Dennis 1979; Jacques 1974, 1976; Rak 1938).

As Lee has pointed out, Chinese illegal immigration across the U.S.Canadian and U.S.-Mexican borders "demonstrates how a seemingly national issue can only be understood in a wider, transnational context" (Lee 2003, 152). It was precisely this understanding that the U.S. Congress appeared to lack when it first enacted the Chinese Exclusion Law in 1882, and it was only after Canada and Mexico adopted similar exclusion policies that surreptitious entry into the United States began to decline. But up until this time, the immigration policies of Canada and Mexico functioned as critical opportunity structures enabling Chinese noncompliance with the exclusion laws in the United States. The political cartoon in Figure 5, entitled "The Back Door," depicts precisely such a situation with respect to the 


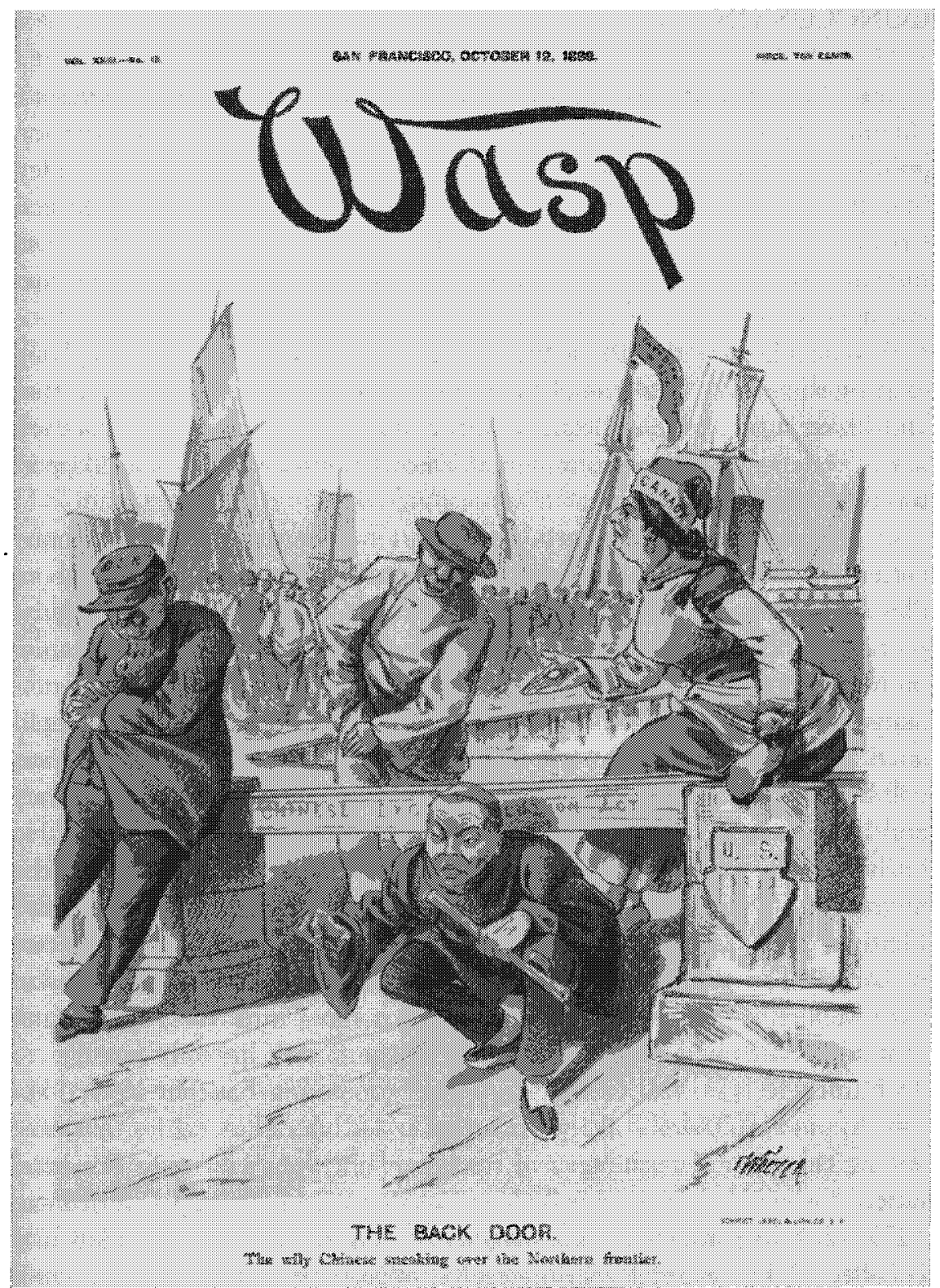

Figure 5. "The Back Door." The Wasp, v. 23, July-Dec. 1889. Courtesy of the Bancroft Library, University of California, Berkeley.

U.S.-Canadian border. It shows a Chinese man who is crawling under a gate labeled, "Chinese Exclusion Act," unnoticed by the dozing gatekeeper on the American side. Presumably, the Chinese man has paid the Canadian gatekeeper his head tax, as required by Canadian law, before entering the United States through the Canadian "back door." 


\section{CONCLUSION}

In this article, I have sought to capture the struggle between a nation state claiming absolute sovereignty over its borders through race-based restriction policies and immigrants who defied that power by illegally crossing the border. In explaining the illegal Chinese border crossings during the exclusion era, I have tried to show that it is important to consider not only economic or instrumental reasons for noncompliance, but also the role of normative values and opportunity structures for noncompliance. On a more general level, one of the major goals of this article has been to take the first step toward applying existing theories of legal compliance to explain illegal immigration. To that end, I have suggested that the probability of noncompliance with immigration law is likely a function of instrumental reasons, normative values, and opportunity structures for evasion.

This basic framework may be very useful in understanding contemporary patterns of illegal immigration. For example, although current debates about illegal Mexican immigration have tended to focus almost exclusively on the economic incentives for migration, even a cursory reading of the literature on Mexican immigration into the United States shows the salience of normative values among Mexican immigrants in explaining their noncompliance. According to Jorge Vargas $(2001,11)$, for example, "Today, Mexicans still believe the treaty [1848 Treaty of Guadalupe Hidalgo] was an arbitrary and illegal act, and that those lands legitimately belong to Mexico." He further argues that this is a powerful sentiment that continues to fuel the migration of Mexicans into the United States (Vargas 2001, 6; see also Martinez 1988, 2-3). As pointed out in a 1922 report to the U.S. Secretary of Labor, "The psychology of the average Mexican alien unskilled worker from Mexico is that when he enters in any manner into the United States that he is only upon a visit to an unknown portion of his own country.... To him there is no real or imaginary line" (quoted in Sanchez 1993, 15).

In practice, there is likely a complex set of interrelationships that exist among the three determinants of noncompliance. As Lawrence Friedman noted, "behavior does not break down into separate little sticks" (Friedman 1975,122 ). In particular, moral judgments about the fairness of the law may be affected by material self-interest or opportunities for noncompliance (Suchman 1997, 495; Klepper and Nagin 1989, 23). For example, increased enforcement at the U.S.-Mexico border may signal changes in the opportunity structure to those contemplating a border crossing, but such changes may also lead to outcomes - e.g., growing number of Mexican border crossers dying in the desert (see, e.g., New York Times, May 23, 2004, p. 1) -that heighten the perception that the U.S. immigration system is cruel and inhumane. In these ways, if the three factors are, in some sense, mutually reinforcing or have a moderating influence on each other, it may be difficult to isolate the effect of each factor on law-abiding behavior. Nonetheless, advancing 
research in this area will require exploring questions such as: Under what circumstances does one factor become more salient than the other? How does the relative salience of each factor change when other behavioral or social conditions change? Which factor prevails in cases of conflict?

Application of the legal compliance theory to contemporary illegal immigration must also consider specific historical contexts in which different groups of illegal immigrants have come to occupy their respective positions in contemporary American society. The experience of European illegal immigrants in the United States, for example, is vastly different from the experience of illegal immigrants from Central or South America (Corcoran 1993). And these experiences, in turn, are likely to inform the attitudes and perspectives of those in their countries of origin who are contemplating illegal migration. In addition, perceptions about the substantive or procedural fairness of the U.S. immigration laws may be significantly influenced by each group's unique history of international relations with the United States. The challenge, then, as with all social scientific inquiry, is to draw useful generalizations that are sensitive to and informed by the particularities of the immediate subjects under scrutiny.

Finally, future research on noncompliance with immigration law may benefit from a careful consideration of issues that arise from the unique position that immigration law occupies in our legal system. Specifically, as the only domestic law that is entirely directed toward regulating the behavior of noncitizens, it implicates a host of complex issues that may not be as relevant when analyzing law-abiding behavior in other areas of domestic law. For example, immigrants inevitably bring with them their own unique cultural beliefs and biases toward the law and legal authorities, which are likely to impact their interactions with the U.S. immigration system. Admittedly, to the extent that immigrants continue to maintain a strong sense of national or cultural identity, differences in cultural attitudes toward the law may also pose a similar issue in other areas of domestic law (Tyler et al. 1997; Tyler 2000; Huo and Tyler 2000; Darley, Tyler and Bilz 2003). However, this issue is nowhere more salient than in the context of immigration law, which serves as the point of first contact between immigrants and the U.S. legal system. Whether and to what extent one's status as a nonmember may influence his or her behavioral compliance with the laws of another nation is an empirical question that has significant implications for research in this area. These, and other related issues remain important theoretical and empirical challenges for future research on issues of noncompliance with immigration law.

\section{REFERENCES}

Bachman, Ronet, Raymond Paternoster, and Sally Ward. 1992. The Rationality of Sexual Offending: Testing a Deterrence/Rational Choice Conception of Sexual Assault. Law and Society Review 26:343-72. 
Bangarth, Stephanie D. 2003. "We Are Not Asking You to Open Wide the Gates for Chinese Immigration": The Committee for the Repeal of the Chinese Immigration Act and Early Human Rights Activism in Canada. Canadian Historical Review 84:395-422.

Baureiss, Gunter. 1987. Chinese Immigration, Chinese Stereotypes, and Chinese Labour. Canadian Ethnic Studies 19:15-34.

Becker, Gary S. 1968. Crime and Punishment: An Economic Approach. Joumal of Political Economy 76:169-217.

Calavita, Kitty. 2000. The Paradoxes of Race, Class, Identity, and "Passing": Enforcing the Chinese Exclusion Acts, 1882-1910. Law and Social Inquiry 25:1-40.

Chan, Anthony B. 1982. Chinese Bachelor Workers in Nineteenth-Century Canada. Ethnic and Racial Studies 5:513-34.

Chavez, Leo. 1998. Shadowed Lives: Undocumented Immigrants in American Society. Fort Worth, TX: Harcourt Brace College Publishers.

Chen, Helen. 1980. Chinese Immigration into the United States: An Analysis of Changes in Immigration Policies. Ph.D. diss. Advanced Studies in Social Welfare, Brandeis University, Waltham, MA.

Chen, Yong. 2000. Chinese San Francisco, 1850-1943. Stanford, CA: Stanford University Press.

Chin, Ko-lin. 1999. Smuggled Chinese: Clandestine Immigration to the United States. Philadelphia: Temple University Press.

Chinn, Thomas W., H. Mark Lai, and Philip P. Choy, eds. 1969. A History of the Chinese in Califomia: A Syllabus. San Francisco: Chinese Historical Society of America.

Chiswick, Barry R. 1988. Illegal Aliens: Their Employment and Employers. Kalamazoo, MI: W.E. Upjohn Institute for Employment Research.

Cloward, Richard A. and Lloyd E. Ohlin. 1960. Delinquency and Opportunity: A Theory of Delinquent Gangs. New York: Free Press.

Coleman, James William. 1987. Toward an Integrated Theory of White-Collar Crime. American Joumal of Sociology 93:406-39.

Con, Harry, Ronald J. Con, Graham Johnson, Edgar Wickberg, and William E. Willmott. 1982. From China to Canada: A History of the Chinese Communities in Canada. Toronto: McClelland and Stewart.

Corcoran, Mary P. 1993. Irish Illegals: Transients between Two Societies. Westport, CT: Greenwood Press.

Cott, Kennett. 1987. Mexican Diplomacy and the Chinese Issue, 1876-1910. Hispanic American Historical Review 67:63-85.

Craib III, Raymond B. 1996. Chinese Immigrants in Porfirian Mexico: A Preliminary Study of Settlement, Economic Activity and Anti-Chinese Sentiment. Albuquerque, NM: Latin American Institute.

Curtis, James R. 1995. Mexicali's Chinatown. Geographical Review 85:335-48.

Darley, John, Tom R. Tyler, and Kenworthey Bilz. 2003. Enacting Justice: The Interplay of Individual and Institutional Perspectives. In The Sage Handbook of Social Psychology, eds. Michael A. Hogg and Joel Cooper, 458-76. Thousand Oaks, CA: Sage Publications.

Daniels, Roger. 1986. Chinese and Japanese in North America: The Canadian and American Experiences Compared. Canadian Review of American Studies 17:173-87.

Daniels, Roger. 2004. Guarding the Golden Door: American Immigration Policy and Immigrants since 1882. New York: Hill and Wang.

Delgado, Grace Peña. 2004. At Exclusion's Southern Gate: Changing Categories of Race and Class among Chinese Fronterizos, 1882-1904. In Continental Crossroads: Remapping U.S.-Mexico Borderlands History, eds. Samuel Truett and Elliott Young, 295-332. Durham, NC: Duke University Press.

De Lorme, Ronald L. 1973. The United States Bureau of Customs and Smuggling on Puget Sound, 1851-1913. Prologue. Summer, 77-88.

Dennis, Philip A. 1979. The Anti-Chinese Campaigns in Sonora, Mexico. Ethnohistory 26:65-80. 
Fartar, Nancy. 1972. The Chinese in El Paso. El Paso, TX: Texas Western Press.

Fong, Julia. 1999. The Fong Family History: Stories of My Father's Side of the Family. In Chinese America: History and Perspectives, 47-61. San Francisco: Chinese Historical Society of America.

Friedman, Lawrence M. 1975. The Legal System: A Social Science Perspective. New York: Russell Sage Foundation.

Fritz, Christian G. 1988. A Nineteenth Century "Habeas Corpus Mill": The Chinese before the Federal Courts in California. American Journal of Legal History 32:347-72.

Fuchs, Laurence H. 1990. American Kaleidoscope: Race, Ethnicity, and the Civic Culture. Hanover, NH: Wesleyan University Press.

Fry, C. Luther. 1928. Illegal Entry of Orientals into the United States between 1910 and 1920. Joumal of the American Statistical Association 23:173-77.

Gibbs, Jack P. 1986. Deterrence Theory and Research. In The Law as a Behavioral Instrument, ed. Gary B. Melton, 87-130. Lincoln, NE: University of Nebraska Press.

Grasmick, Harold G. and George J. Bryjak. 1980. The Deterrent Effect of Perceived Severity of Punishment. Social Forces 59:471-91.

Gyory, Andrew. 1998. Closing the Gate: Race, Politics, and the Chinese Exclusion Act. Chapel Hill: University of North Carolina Press.

Hsu, Madeline. 1997. Gold Mountain Dreams and Paper Son Schemes. In Chinese America: History and Perspective, 46-60. San Francisco: Chinese Historical Society of America.

Hsu, Madeline. 2000. Dreaming of Gold, Dreaming of Home: Transnationalism and Migration between the United States and South China, 1882-1943. Stanford, CA: Stanford University Press.

Hu-DeHart, Evelyn. 1980. Immigrants to a Developing Society: The Chinese in Northern Mexico, 1875-1932. Joumal of Arizona History 21:49-86.

Hu-DeHart, Evelyn. 1982. Racism and Anti-Chinese Persecution in Sonora, Mexico, 1876-1932. Amerasia 9:1-28.

Huo, Yuen J. and Tom R. Tyler. 2000. How Different Ethnic Groups React to Legal Authority. San Francisco: Public Policy Institute of California.

Jacques, Leo M. 1974. The Anti-Chinese Campaigns in Sonora, Mexico, 1900-1931. Ph.D. diss. Department of History, University of Arizona, Albuquerque, NM.

Jacques, Leo M. 1976. Have Quick More Money Than Mandarins: The Chinese in Sonora. Joumal of Arizona History 17:201-18.

Kim, Hyung-chan and Richard W. Markov. 1983. The Chinese Exclusion Laws and Smuggling Chinese into Whatcom County, Washington, 1890-1900. The Annals of the Chinese Historical Society of the Pacific Northwest 16-30.

Kiong, Wong Sin. 2002. China's Anti-American Boycott Movement in 1905. New York: Peter Lang.

Klepper, Steven and Daniel Nagin. 1989. The Anatomy of Tax Evasion. Journal of Law, Economics, and Organization 5:1-24.

Kwong, Peter. 1997. Forbidden Workers: Illegal Chinese Immigrants and American Labor. New York: New Press.

Lai, David Chuenyan. 1988. Chinatowns: Touns within Cities in Canada. Vancouver: University of British Columbia Press.

Lai, Him Mark. 2004. Becoming Chinese American: A History of Communities and Institutions. Walnut Creek, CA: AltaMira Press.

Lau, Estelle. 2000. Paper Families: Identity, Immigration Administration and Chinese Exclusion. Ph.D. diss. Department of Sociology, University of Chicago, Chicago, IL.

Lee, Erika. 2003. At America's Gates: Chinese Immigration during the Exclusion Era, 1882 1943. Chapel Hill: University of North Carolina Press.

Lessig, Lawrence. 1998. The New Chicago School. Journal of Legal Studies 27:661-91.

Lopez, Ian F. Haney. 1996. White by Law: The Legal Construction of Race. New York: New York University Press. 
Ma, L. Eve Armentrout. 1991. Chinatown Organizations and the Anti-Chinese Movement, 1882-1914. In Entry Denied: Exclusion and the Chinese Community in America, 1882-1943, ed. Sucheng Chan, 147-69. Philadelphia: Temple University Press.

Martinez, Oscar J. 1988. Troublesome Border. Tucson: The University of Arizona Press.

McClain, Charles. 1984. The Chinese Struggle for Civil Rights in Nineteenth Century America: The First Phase, 1850-1870. California Law Review 72:529-68.

McClain, Charles. 1994. In Search of Equality: The Chinese Struggle against Discrimination in Nineteenth-Century America. Berkeley and Los Angeles: University of California Press.

McClain, Charles J. and Laurence Wu McClain. 1991. The Chinese Contribution to the Development of American Law. In Entry Denied: Exclusion and the Chinese Community in America, 1882-1943, ed. Sucheng Chan, 3-24. Philadelphia: Temple University Press.

McKendall, Marie A. and John A. Wagner. 1997. Motive, Opportunity, Choice, and Corporate Illegality. Organization Science 8:624-47.

Meier, Kenneth J. and David R. Morgan. 1982. Citizen Compliance with Public Policy: The National Maximum Speed Law. Western Political Quarterly 35:258-73.

Nagin, Daniel S. 1998. Criminal Deterrence Research at the Outset of the Twenty-First Century. Crime and Justice 23:1-42.

Ngai, Mae M. 1998. Legacies of Exclusion: Illegal Chinese Immigration during the Cold War Years. Joumal of American Ethnic History 18:3-35.

Ngai, Mae M. 2004. Impossible Subjects: Illegal Aliens and the Making of Modern America. Princeton, NJ: Princeton University Press.

Paternoster, Raymond, Robert Brame, Ronet Bachman, and Lawrence W. Sherman. 1997. Do Fair Procedures Matter? The Effect of Procedural Justice on Spouse Assault. Law and Society Review 31:163-204.

Paulus, Ingeborg and Carl Simpson. 1981. Opportunity, Benefit, and Subjective Disposition: Determinants of Nonprofessional Smuggling. The Pacific Sociological Review 24:299-327.

Perkins, Clifford Alan. 1978. Border Patrol: With the U.S. Immigration Service on the Mexican Boundary, 1910-54. El Paso, TX: Texas Western Press.

Posner, Richard A. 1972. Economic Analysis of Law. Boston: Little, Brown.

Rak, Mary Kidder. 1938. Border Patrol. Boston: Houghton Mifflin Company.

Ralph, Julian. 1891. The Chinese Leak. Harper's New Monthly Magazine 82:515-25.

Robinson, Paul H. and John M. Darley. 1997. The Utility of Desert. Northwestern University Law Review 91:453-99.

Roy, Patricia E. 1976. The Preservation of the Peace in Vancouver: The Aftermath of the Anti-Chinese Riot of 1887. BC Studies. Autumn, 44-59.

Salyer, Lucy E. 1995. Laws Harsh as Tigers: Chinese Immigrants and the Shaping of Modern Immigration Law. Chapel Hill: University of North Carolina Press.

Sanchez, George J. 1993. Becoming Mexican American: Ethnicity, Culture and Identity in Chicago Los Angeles, 1900-1945. New York: Oxford University Press.

Schatkin, Sidney B., Leon N. Sussman, and Dorris Edward Yarbrough. 1955. Chinese Immigration and Blood Tests. Criminal Law Review 2:44-56.

Scheinberg, Ellen. 1994. Evidence of "Past Injustices": Records Relating to the Chinese Head Tax. The Archivist 20:26-30.

Shaw, Clifford R. and Henry D. McKay. 1942. Juvenile Delinquency and Urban Areas. Chicago: University of Chicago Press.

Shone, Huie Yuk. 1989. Life Is Like Dream: Confessions of an Illegal Alien. In Chinese America: History and Perspectives, 87-110. San Francisco: Chinese Historical Society of America.

Smith, Kent W. 1992. Reciprocity and Fairness: Positive Incentives for Tax Compliance. In Why People Pay Taxes, ed. Joel Slemrod, 223-50. Ann Arbor: University of Michigan Press. 
Smith, Kent W. and Karyl A. Kinsey. 1987. Understanding Taxpaying Behavior: A Conceptual Framework with Implications for Research. Law and Society Review 21:639-63.

Smith, Marian L. 2000. The Immigration and Naturalization Service (INS) at the U.S.Canadian Border, 1893-1993: An Overview of Issues and Topics. Michigan History Review 26:127-47.

Stigler, George J. 1970. The Optimum Enforcement of Laws. Joumal of Political Economy 78:526-36.

Suchman, Mark C. 1997. Rational, Normative and Cognitive Perspectives in the Social Scientific Study of Law. Wisconsin Law Review 1997:475-501.

Sung, Betty Lee. 1967. Mountain of Gold: The Story of the Chinese in America. New York: The Macmillan Company.

Tittle, Charles R. 1969. Crime Rates and Legal Sanctions. Social Problems 16:409-23.

Tsai, Shih-shan Henry. 1970. Reaction to Exclusion: Ch'ing Attitudes toward Overseas Chinese in the United States, 1848-1906. Ph.D. diss., Department of History, University of Oregon, Eugene, OR.

Tsai, Shih-shan Henry, 1986. The Chinese Experience in America. Bloomington: Indiana University Press.

Tyler, Tom R. 1990. Why People Obey the Law. New Haven, CT: Yale University Press.

Tyler, Tom R. 2000. Multiculturalism and the Willingness of Citizens to Defer to Law and to Legal Authorities. Law and Social Inquiry 25:983-1019.

Tyler, Tom R. 2003. Procedural Justice, Legitimacy, and the Effective Rule of Law. Crime and Justice 30:283-357.

Tyler, Tom R., Robert J. Boeckmann, Heather J. Smith, and Yuen J. Huo. 1997. Social Justice in a Diverse Society. Denver, CO: Westview.

Tyler, Tom R. and John M. Darley. 2000. Building a Law-Abiding Society: Taking Public Views about Morality and the Legitimacy of Legal Authorities into Account when Formulating Substantive Law. Hofstra Law Review 28:707-39.

Tyler, Tom R. and Yuen J. Huo. 2002. Trust in the Law: Encouraging Public Cooperation with the Police and Courts. New York: Russell Sage Foundation.

U.S. Department of Commerce and Labor. 1906. Facts Concerming the Enforcement of the Chinese-Exclusion Laws. Washington, DC: Government Printing Office.

U.S. Department of Labor. 1916, 1918. Annual Report of the Commissioner General of Immigration. Washington, DC: Government Printing Office.

Vargas, Jorge A. 2001. U.S. Border Patrol Abuses, Undocumented Mexican Workers, and International Human Rights. San Diego International Law Journal 2:1-92.

Wai-man, Lee. 1984. Portraits of a Challenge: An Illustrated History of the Chinese Canadians. Toronto: Council of Chinese Canadians in Ontario.

Wang, Guanhua. 2001. In Search of Justice: The 1905-1906 Chinese Anti-American Boycott. Cambridge, MA: Harvard University Asia Center.

Wong, K. Scott. 1998. Cultural Defenders and Brokers: Chinese Response to the AntiChinese Movement. In Claiming America: Constructing Chinese American Identities during the Exclusion Era, eds. K. Scott Wong and Sucheng Chan, 3-40. Philadelphia: Temple University Press.

Wong, Charles Choy and Kenneth Klein. 1994. False Papers, Lost Lives. In Origins and Destinations: Essays on Chinese America, 355-74. Los Angeles: Chinese Historical Society of Southern California.

Yung, Judy. 1995. Unbound Feet: A Social History of Chinese Women in San Francisco. Berkeley and Los Angeles: University of California Press.

Yung, Judy. 1998. The Fake and the True: Researching Chinese Women's Immigration History. In Chinese America: History and Perspective, 25-56. San Francisco: Chinese Historical Society of America.

Zo, Kil Young. 1978. Chinese Emigration into the United States, 1850-1880. New York: Arno Press. 


\section{CASES CITED}

Chinese Exclusion Case (Chae Chan Ping v. United States), 130 U.S. 581 (1889).

Chin Lund v. United States, 9 F.2d 283 (6th Cir. 1925).

Chow Chok v. United States, 161 F. 627 (N.D.N.Y. 1908).

Fong Yue Ting v. United States, 149 U.S. 698 (1893).

Guan Lee v. United States, 198 F. 596 (7th Cir. 1912).

In re Leo Hem Bow, 47 F. 302 (N.D. Wash. 1891).

In re Mah Wong Gee, 47 F. 433 (D. Vt. 1891).

Jung See v. United States, 4 F.2d 639 (8th Cir. 1925).

Lee Lew You v. United States, 230 F. 820 (2d Cir. 1916).

Lee Sim v. United Stats, 218 F. 432 (2d Cir. 1914).

Lui Lum v. United States, 166 F. 106, 109 (3d Cir. 1909).

Sam Yick v. United States, 240 F. 60 (9th Cir. 1917).

Sit Sing Kum v. United States, 277 F. 191 (2d Cir. 1921).

Toy Tong v. United States, 146 F. 343 (3d Cir. 1906).

United States v. Ah Toy, 47 F. 305 (D. Wash. 1891).

United States v. Chung Fung Sun, 63 F. 261 (N.D.N.Y. 1894).

United States v. Hom Young, 198 F. 577 (S.D.N.Y. 1912).

United States v. Hung Chang, 134 F. 19 (6th Cir. 1904).

United States v. Jew Lee, 16 F.2d 492 (S.D.N.Y. 1926).

United States v. Yuen Pak Sune, 183 F. 260 (N.D.N.Y. 1910).

United States v. Wong Kim Ark, 169 U.S. 649 (1898).

United States ข. Wong You, 223 U.S. 67 (1912).

United States ex rel. Haum Pon v. Sisson, 230 F. 974 (2d Cir. 1916).

United States ex rel. Hen Lee v. Sisson, 232 F. 599 (2d Cir. 1916).

Wallis v. United States, 230 F. 71 (5th Cir. 1916).

Wong Back Sue v. Connell, 233 F. 659 (9th Cir. 1916).

Woo Wai v. United States, 223 F. 412 (9th Cir. 1915).

Yee Yet v. United States, 175 F. 565 (2d Cir. 1910).

\section{STATUTES AND TREATIES}

Act of May 6, 1882, ch. 126, 22 Stat. 58 (1882).

Act of July 5, 1884, ch. 220, 23 Stat. 115 (1884).

Act of September 13, 1888, ch. 1015, 25 Stat. 476 (1888).

Act of May 5, 1892, ch. 60, 27 Stat. 25 (1892).

Act of April 29, 1902, ch. 641, 32 Stat. 176 (1902).

Act of April 27, 1904, ch. 1630, 33 Stat. 394, 428 (1904).

Act of February 20, 1907, ch. 1134, 34 Stat. 898 (1907).

Act of December 17, 1943, ch. 344, 57 Stat. 600 (1943).

Burlingame Treaty, July 28, 1868, U.S.-China, 16 Stat. 739, T.S. No. 48 (1868).

Treaty between the United States and China, Concerning Immigration, November 17, 1880, U.S.-China, 22 Stat. 826, T.S. No. 49 (1880). 


\section{Review Section}

Edited by Howard S. Erlanger

\section{REVIEW ESSAY}

American Exceptionalism and Racialized Inequality in American

Capital Punishment

Paul J. Kaplan

Constitutions and Empires

Lauren Benton

The Law, Religion, and State Making in the Early Modern World:

Protestant Revolutions in the Works of Berman, Gorski, and Witte

$$
\text { A. G. Roeber }
$$

Communities and Culture: Enriching Legal Consciousness and

Legal Culture

Anna-Maria Marshall

BOOK NOTES

Howard S. Erlanger is Voss-Bascom Professor of Law and Professur of Sociology at the University of Wisconsin, Madison. 
$* * *$ 